بررسى كارايى تالابهاى مصنوعى زيرسطحى هيبريدى در كاهش بار آلى بِاب تصفيهخانهاى فاضلاب شهرى با استفاده از گياهان آبزى مختلف

امير حقشناس آدرمنابادى'، منوجهر حيدريور' و صالح تركش اصفهانى'

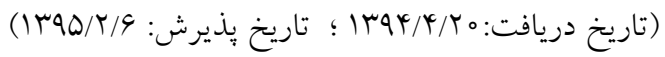

جكيده

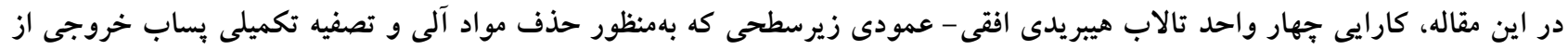

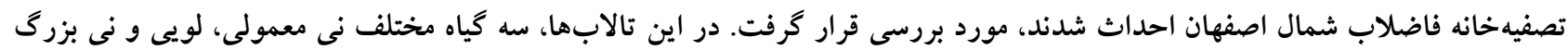

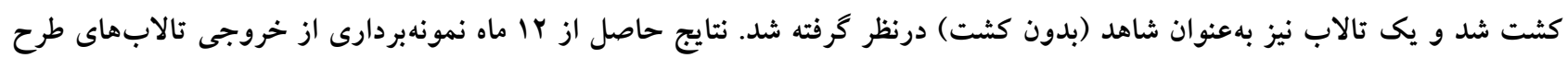

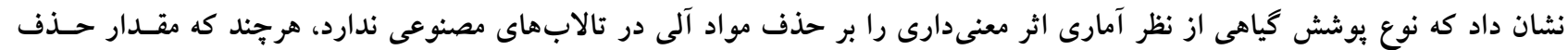

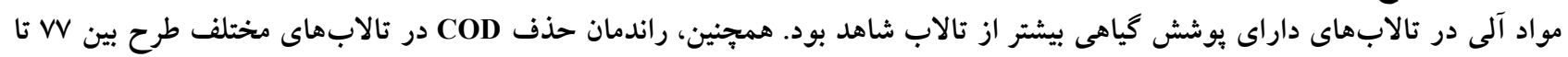

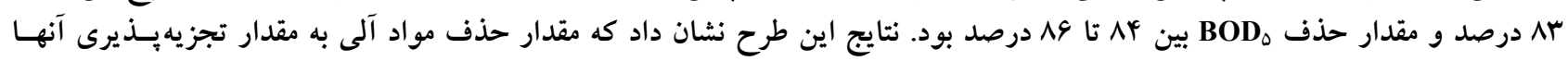

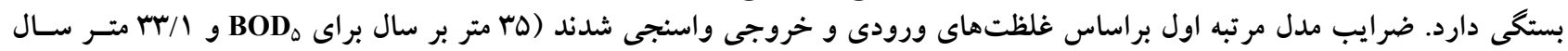

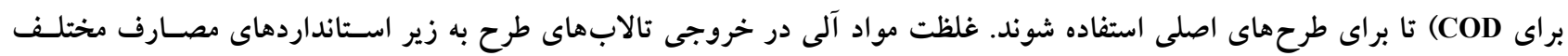

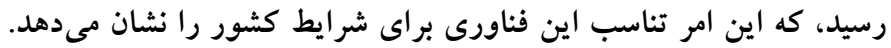

وازههاى كليدى: تالاب مصنوعى، بوشش گياهى، بازيافت بـاب، COD BOD، 
بـا جريـان زيرسـطحى (Subsurface Constructed Wetlands)

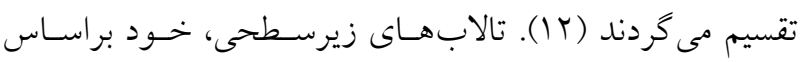

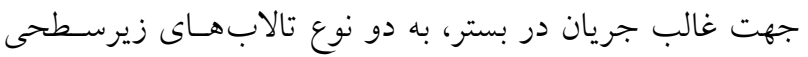
افقــى (Horizontal Flow Constructed Wetlands) تابلابهاى زيرسطحى عمـودى ( Vertical Flow Constructed تقسيمبندى مىشوند. تالابهاى سطحى بهدئيل دارس (Wetlands بودن هزينه انــدى و ارزش زيـاد بـراى حيـات وحسش، بيشـتر

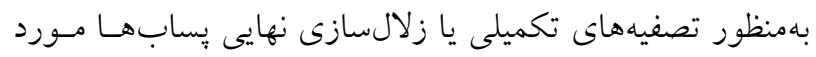

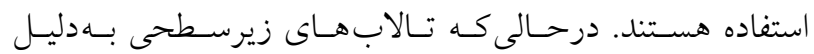

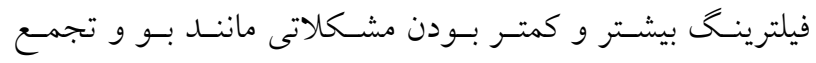
حشرات و در معرض نبودن پِاب با محيط، امروزه بيشتر مورد

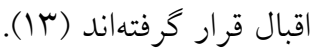
از دهه 1999، كونه جديـــى از تـالابهـاى مصـنوعى كـه. تركيبى از جند تالاب مصنوعى مختلف است بسيار مورد توجـه

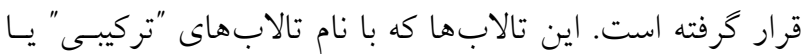

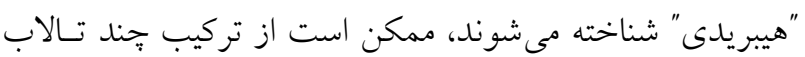

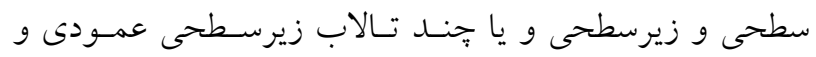

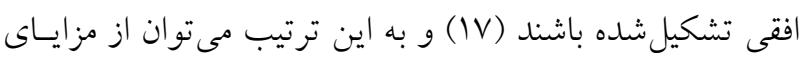

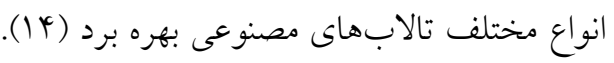

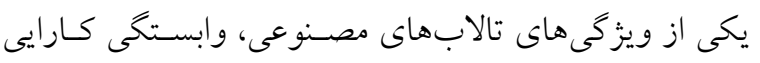

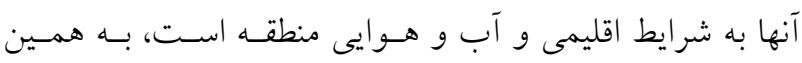

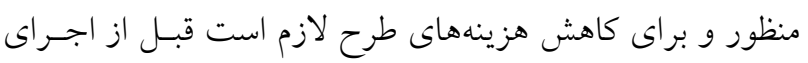

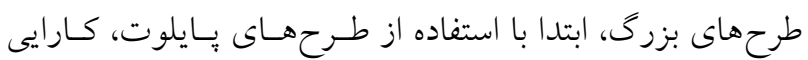
تالاب براى هر منطقه سنجيده شده و در واقع اين فناورى بـراى شر ايط موجود هر منطقه "بومى سازى" شود. يكى از مواردى كـهـ در بومى سازى تالابهاى مصنوعى مورد توجه اسـت شناسـيى لئي كياهان رايج در منطقه است كه با شرايط هميشـهـ اشـباع تـالاب ساز كار بوده و بتوانند بهعنوان يوشش كياهى در ايسن تـالابهـا مورد استفاده قرار گيرند. استفاده از خياهان بومى مزايايى از قبيل آسانى دسترسى، كاهش هزينه هاى طرح، رشد سريع و هم:جنين

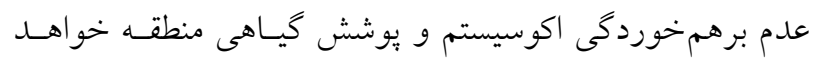
شد (9). نسى معمـولى يـا استر اليايى (Phragmites australis)

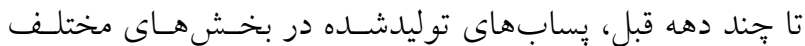

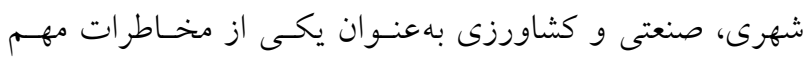
بهداشتى و زيست محيطى در جوامع مختلف تلقى مى شدند. اما

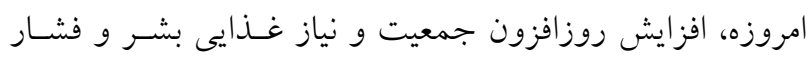

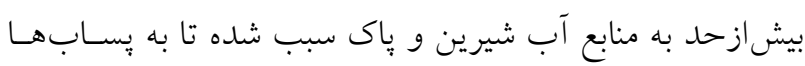

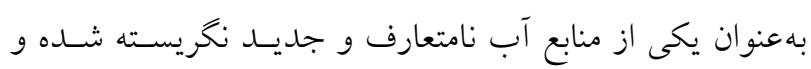

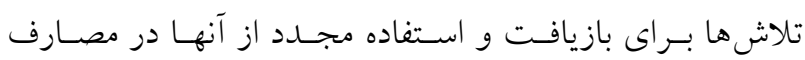

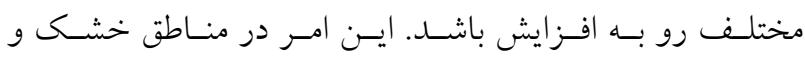

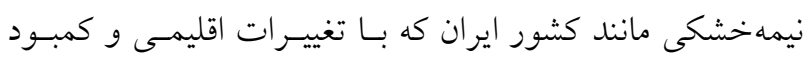
بارش مواجه هستند ضرورى تر بهنظر مىرسد.

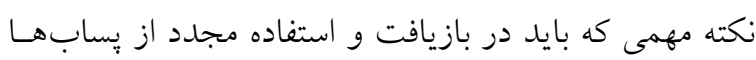

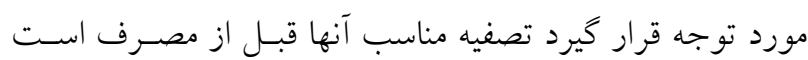

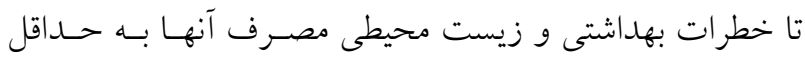

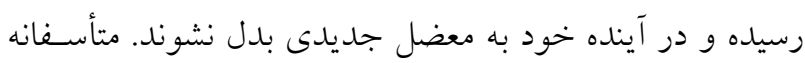

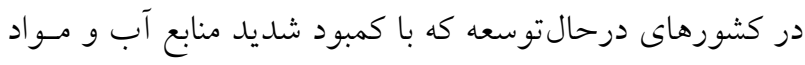

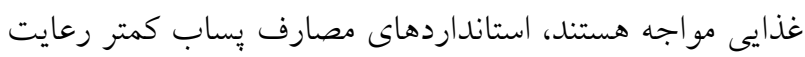

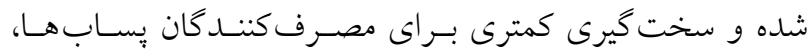

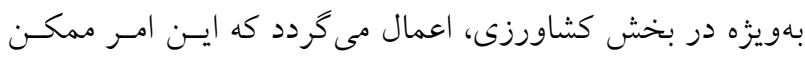

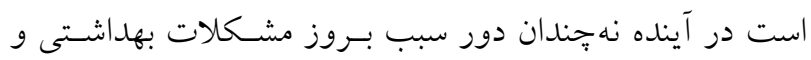
زيست محيطى گردد. تـالابهـاى مصسنوعى (Constructed Wetlands) يكسى از

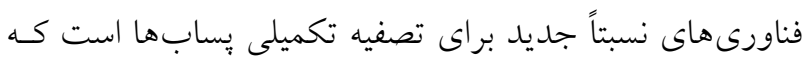

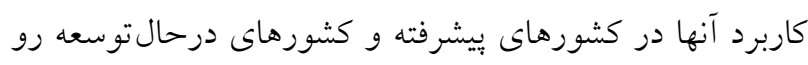

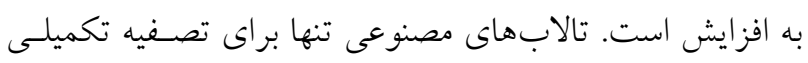

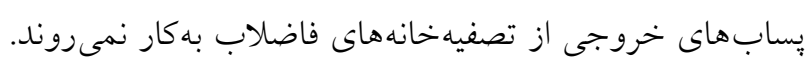

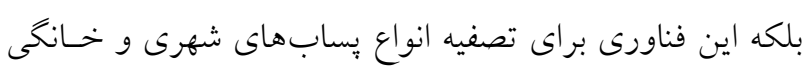

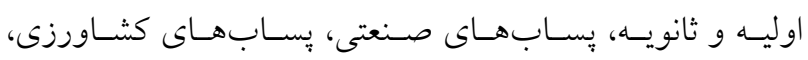

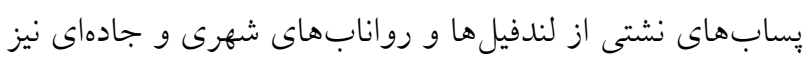

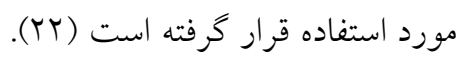
تالابهاى مصنوعى به دو گروه عمده تالابهاى بـا جريـان

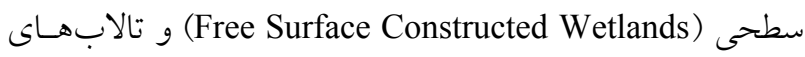


در دنيا براى تصفيه تكميلى بِابهاى شهرى مورد استفاده قرار

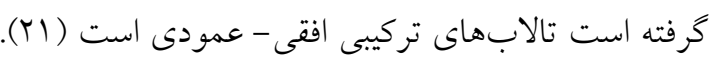

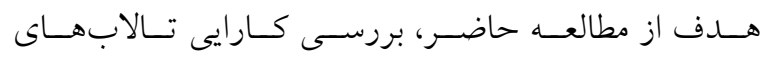

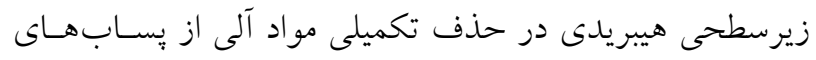

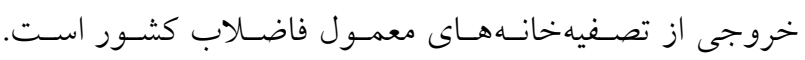

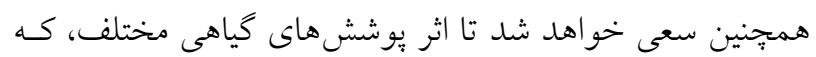

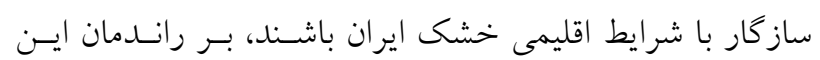

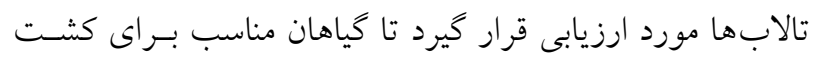

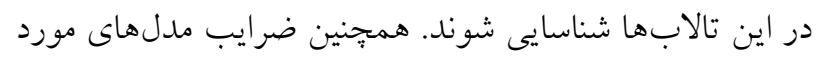

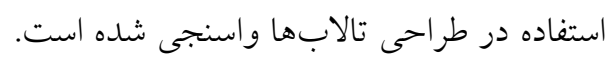

\section{مواد و روشها \\ محل اجراى طرح}

بهمنظور بومىسازى فناورى تالاب مصنوعى زيرسطحى جهـت تصفيه تكميلى بسـاب خروجسى تصفيه خانـه فاضـلاب شـمال اصفهان، در سال بهوب جهار واحد تالاب زيرسطحى هيبريسدى

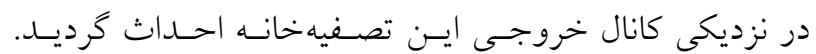

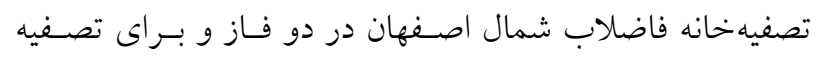

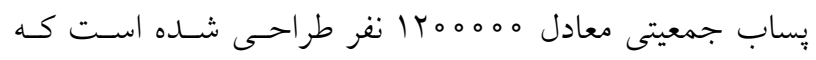

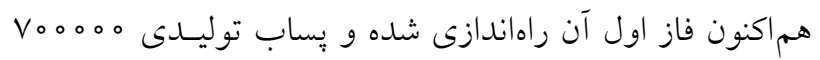

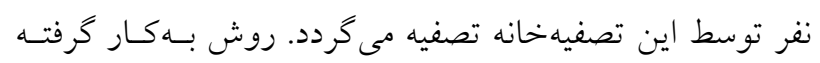

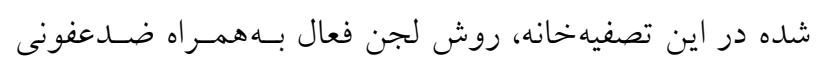

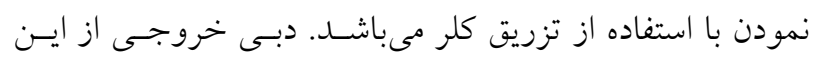
تصفيه بيش از \&\$ا هزار مترمكعب بر روز مىباشد.

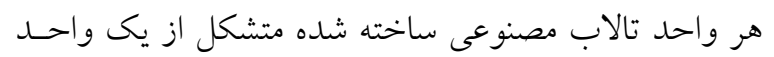

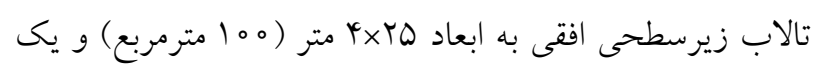

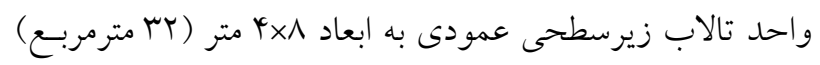

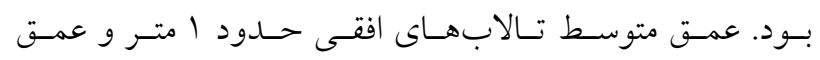

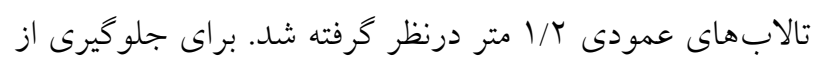

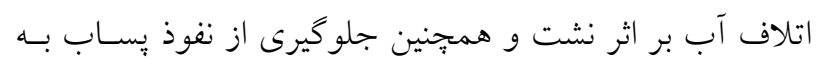

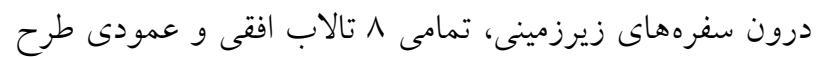

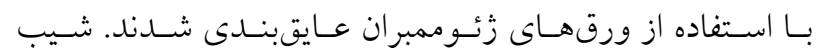

يركاربردترين كياه در ميان كياهان آبزى است كه در تالابهـاى مصنوعى زيرسطحى مورد استفاده است و يـس از آن نيـز كيـاه

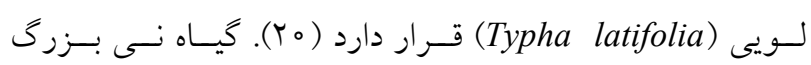
نيـز از جملـه كياهـانى اسـت كـه اخيـراً در (Arundo donax) تالاب هاى مصنوعى در نقاط مختلف دنيـا مـورد آزمـايش قـرار

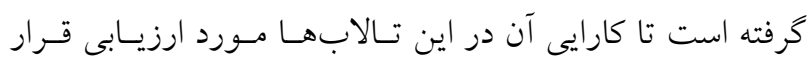

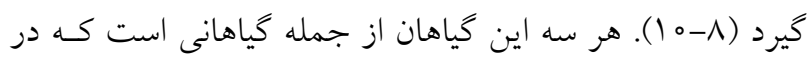

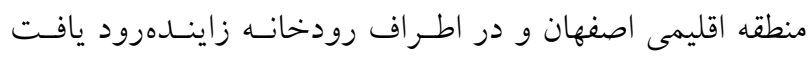

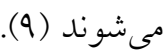

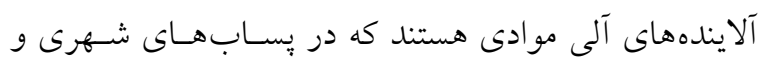

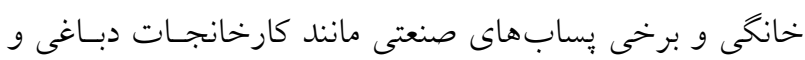

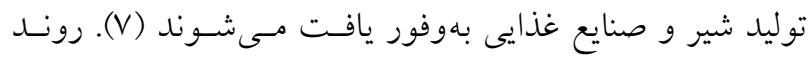

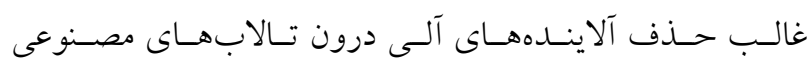
زيرسطحى را مىتوان در فيلتراسيون و ترسيب و تجزيه هـوازى

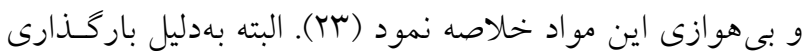

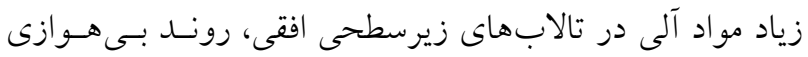

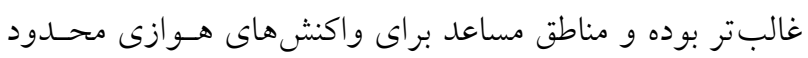

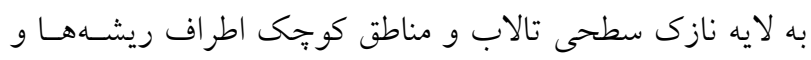

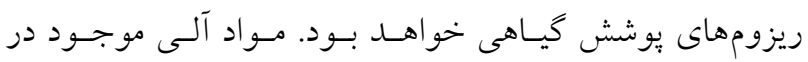

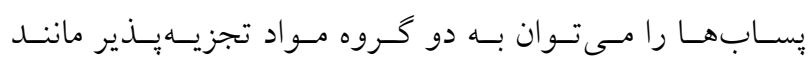

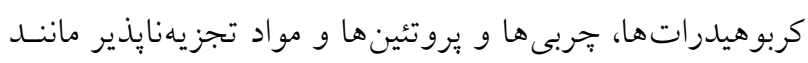

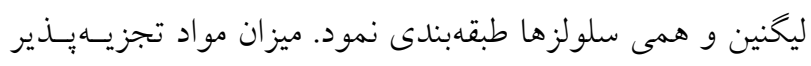

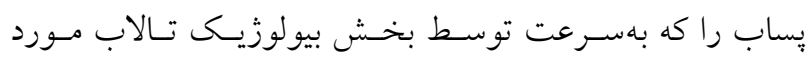

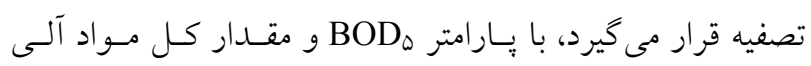

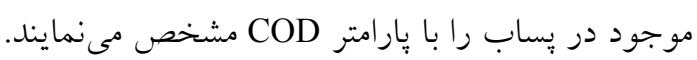

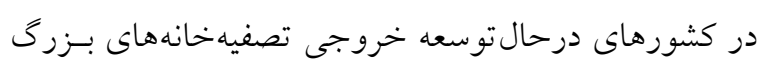

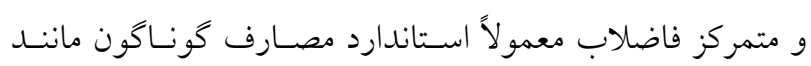

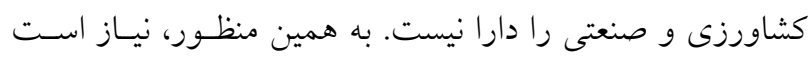

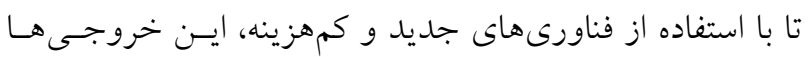

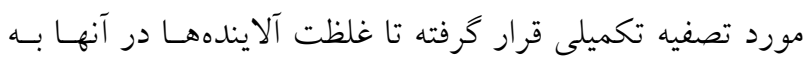

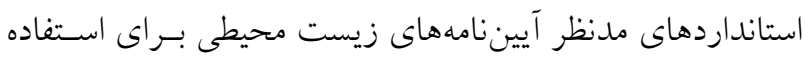

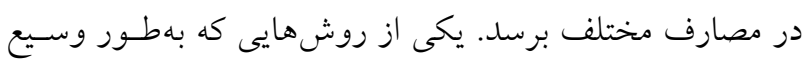



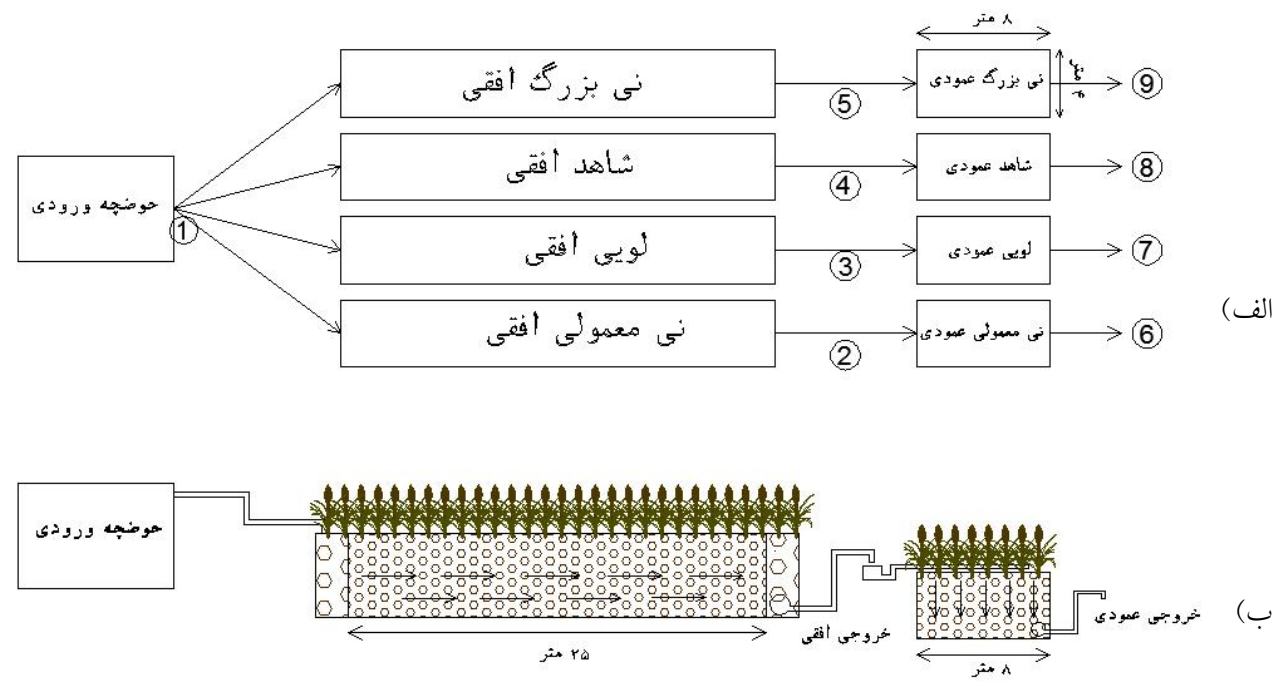

شكل 1. الف) پِان و ب) سطح مقطع تالابهاى هيبريدى ساخته شده در تصفيهخانه فاضلاب شمال اصفهان. نقاط ا تا ه نقاط نمونهبردارى مي باشند

سبب يكنو اختى عرضى ورود جريان يساب بـه بسـتر متخلخـل

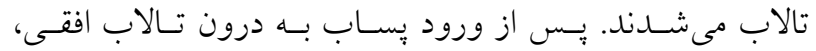
جريان در راستاى افق بستر تـالاب راطى نمـوده و در انتهـاى تالاب با استفاده از يك لوله زهكش عرضى كه در كـف تـالاب

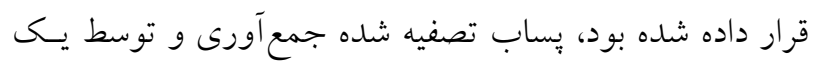
سيفون U شكل به بيرون تالاب انتقال داده مىشد (شكل ()). يساب خروجى از تالابـهاى افقى بـا اسـتفاده از يـكى لولـه مستقيم به تالابهاى عمودى منتقل شده و با استفاده از دو لوله سوراخدار كه در سطح اين تالابها تعبيه شـده بـود بـه آرامسى

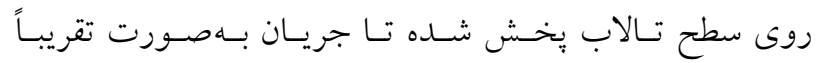
يكنواخت شروع به نفوذ عمودى درون بستر اين تالابها نمايد. يس از عبور عمودى يُاب از درون بستر متخلخل، با استفاده از

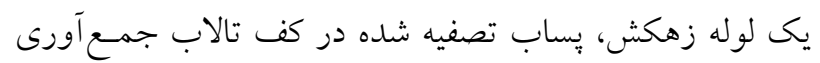
شده و توسط يك سيفون U شكل به بيـرون تـالاب انتقـال داده بر طبق برنامه نمونهبردارى، در هر ماه يك نمونسه از يسـاب ورودى به تالابها و هشت نمونه از خروجى تالابهاى افقى و عمودى برداشت شد. يُس از اتمام هر نمونسهبــردارى، نمونـهـهـا

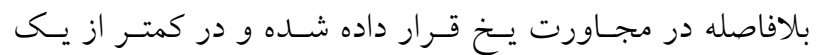
ساعت به آزمايشخاه آلودگى محيط زيست دانشكده منابع طبيعى
كف تالاب بهسمت خروجى برابر / /ه متر بر متر تنظيم گرديد. بهمنظور مقايسـه اثـر كياهـان مختلـفـ بـر رانــدمان تـالاب هيبريدى در كاهش آلايندهاى آلى، سـه نــوع گيـاه تـالابى نسى معمـولى يـا اسـتر اليايى (Phragmites australis)، نسى بـزررى و لــيى (Arundo donax) شرايط اقليمى اصفهان بوده و در نقاط مختلـف قابـل دسترسى

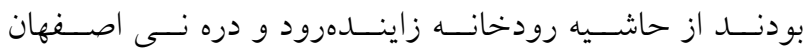
جمع آورىشده و به محل تالابها انتقال داده شـدند. هـر گيـاه بهطور تصادفى با تراكم ب تا ب گياه در هر مترمربـع در يكى از واحدهاى تالاب هيبريدى كشت شده و يك تالاب نيز بهعنـوان تالاب شاهد بــدون كشـت رهـا شـــ. بِــاب جـارى در كانـال تصفيه خانه توسط سيستم يمياز به استخر ذخيره سازى و متعادل سازى يُاب در مجاورت طرح منتقل شده و سيس با استفاده از

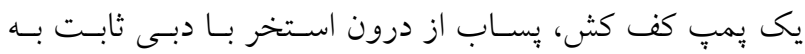
درون حوضجه ورودى طرح يمياز مسىشـد. يسـاب ورودى بـه حوضجه از طريق جهار سرريز روزنهاى به قطر ه/ إسـانتىمتر به درون تالابهاى افقى تزريـق مسى گشـت. در ابتـداى ورودى تالابهاى افقى، در منطقهاى بهطول ه/ه متر، از قلوهسنگ بسيار درشت (قطر متوسـط ه9 ميلسىمتـر) اسـتفاده شـــ ايسن قلـوه سنخ هاى درشت با نفوذيذيرى بسيار بالا نسبت به بستر تالاب، 


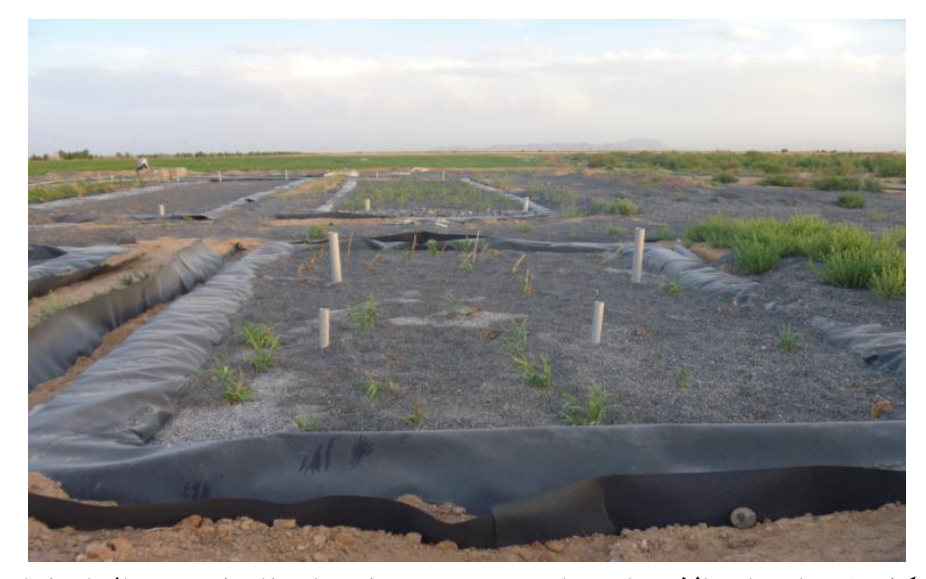

شكل r. نمايى از تالابهاى ساختهده در تصفيهخانه فاضلاب شمال اصفهان

ايجاد طرحهاى بايلوت واسنجى ضـرايب مـدلهـاى كيفى در شرايط واقعى بهرهبردارى بـهـنظـور تخمسين سـطح لازم بـراى طرحهاى تالابهـاى مصـنوعى در مقيـاس اصـلى اسـت (YY).

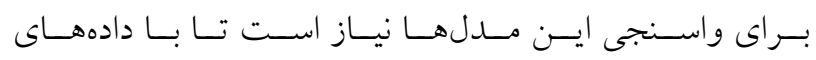
اندازه كيرىشده در طرح، ثابتهاى معادلات واسنجى شـوند تـا براى طرحهاى اصلى با شرايط مشابه قابل توصيه باشند.

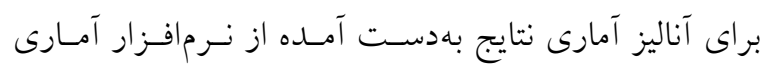
ANOVA استفاده شد. از آزمون تجزيـه واريـانس يـا SPSS19 براى تعيين اختلافات معنى دار بين تيمارها استفاده شده و بـراى

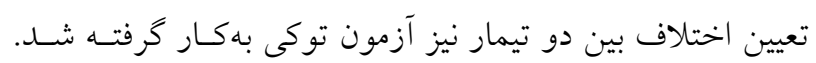
مقايسات آمارى در سطح معنى دار هـ انجام كرفت.

نتايج اندازه كيرى دبى در ماههاى مختلـف نشـان داد كـه مقــدار دبسى ورودى به تالابها بين ه مترمكعب بر روز در بهمن بهوسا تا 9 مترمكعب بر روز در مـرداد سوس| متغيـر بــوده اسـت. بـهــور متوسط، دبى ورودىى به تالابها در كل طول دوره بهــــبـردارى

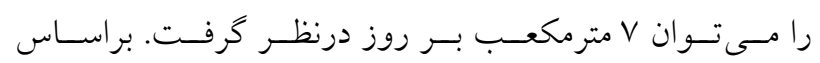
آزمايشهاى دانهبندى انجام كرفته روى تالاب كه تخلخل بسـتر

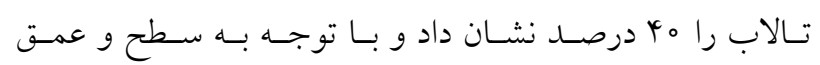
تالابهاى افقى، مىتوان بيان نمود كه بـار هيــروليكى ورودى به تالابهاى افقى و عمودى بهترتيب Vو اب سانتى متر بـر روز
دانشخاه صنعتى اصفهان منتقل شده و آناليزهاى كيفى در همـان

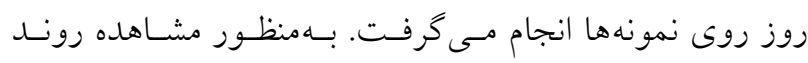
تغييرات كارايى تالاب در طـول زمـان و فصـول مختلـف، دوره نمونهبردارى r| ماه درنظر كرفته شد. دبى ورودى به هر تـالاب نيز در طول كا ماه بهصورت هر دو يا سه روز يكبار با استفاده از پيايش سطح آب يشت روزنه و همجنين با اسـتفاده از ظـرف مدرج و زمانسنج اندازه كيرى و ثبت گرديد. نمـايى از يـايلوت ساختهشده در شكل (Y) نمايش داده شده است. مدل سينتيك مرتبه اول رايجترين و سادهتـرين مــل بـراى طراحى و تعيين مساحت مورد نياز تالابهاى زيرسطحى افقى

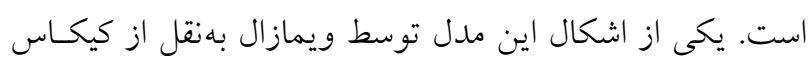

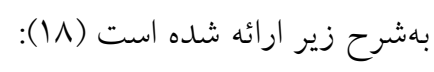
$\mathrm{A}_{\mathrm{S}}=\frac{\mathrm{Q}^{*} \operatorname{Ln}\left[\frac{\mathrm{C}_{\text {in }}}{\mathrm{C}_{\text {out }}}\right]}{\mathrm{K}_{\mathrm{BOD}}}$ كه در آن As سطح تالاب (مترمربـع) و KBOD ثابـت معادلـه برحسب متر بر روز يا متر بر سال است. براساس نظـر ويمـازال

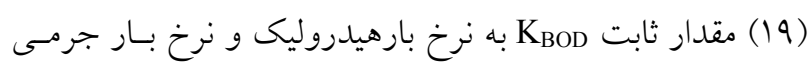
آلاينده ورودى به تالاب وابسته بوده و با افزايش ايسن پيارامترهـا افزايش خواهد يافت. استفاده از ضريب مرتبه اول سبب خواهد

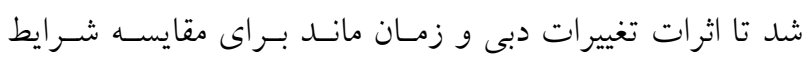
مختلف حـذف كرديـده و امكـان مقايسـه كـارايى تـالابهـاى

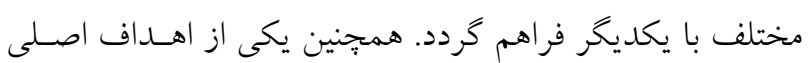



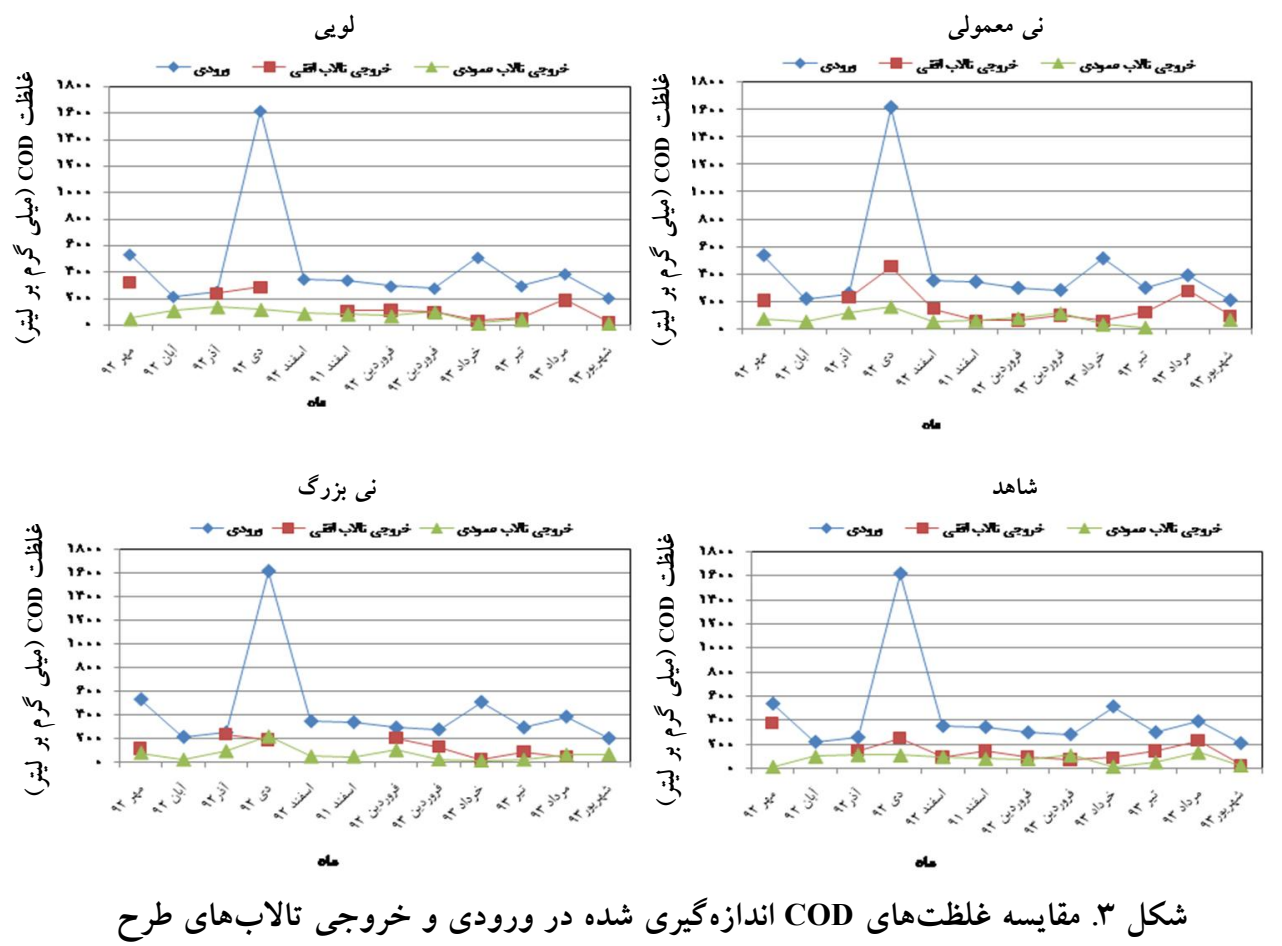

مىباشد. بيشترين غلظت COD در خروجى تـالاب نـى معمـولى

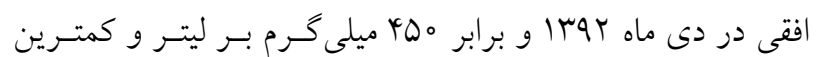

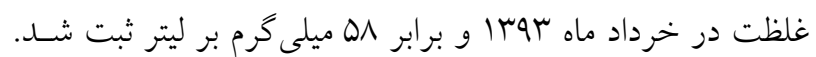
در خروجى تالاب زير سطحى افقى كشت شــه بـا كيـاه لـويى،

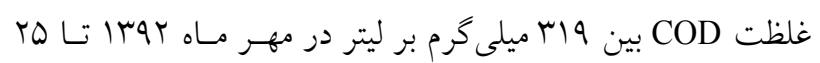

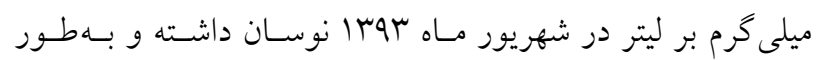

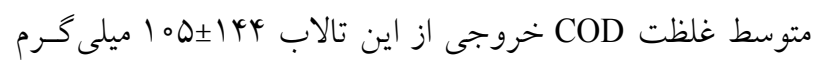
بر ليتر بهدست آمد. نوسانات غلظت COD در خروجسى تـالاب

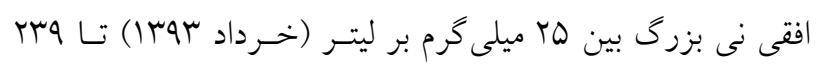

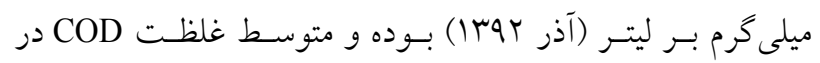

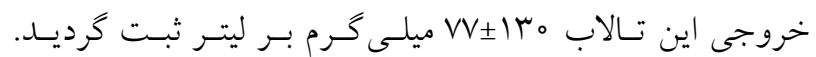
متوسط غلظت خروجى در تالاب افقى شاهد بيشتر از تالابهـاى

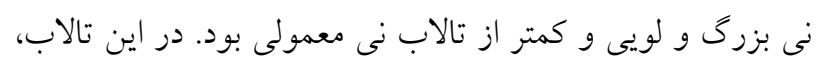

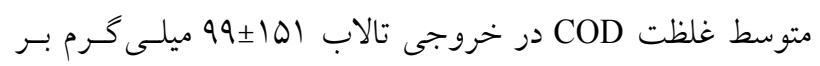
ليتر و بازه تغييرات بين RV ميلى گرم بر ليتر در شهريور ماه سوسا

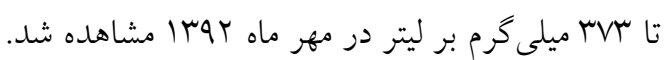

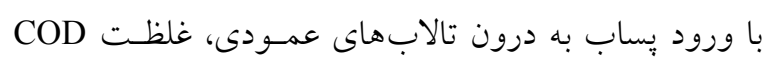

مىباشد. همجنين زمان ماند تئورى هر واحـــ تـالاب هيبريـدى حدود ^ روز محاسبه گرديد. نتايج حاصل از آناليز يارامتر COD نمونههاى اخـــ شــده از محل طرح در شكل (r) نشان داده شده اسـت. مقــار غلظـت در ورودى تالاب بين Y COD

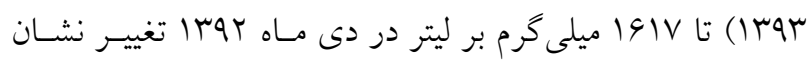

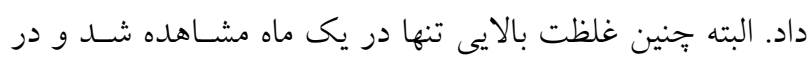
11 ماه ديخر سال غلظت COD همواره كمتر از ه هـ ميلى كـرم بر ليتر بود. بـا صـرف نظـر از غلظـت COD در دى مـاه بوسا، بهطور متوسط غلظت ورودى به تالابهاى طـرح در كـل دوره

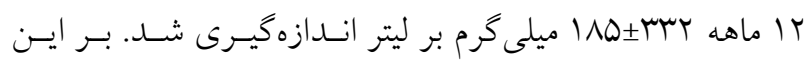
اساس و با توجه به متوسط دبى ورودى به تالابها در كل دوره بهرهبردارى مقدار بار COD ورودى به تالابهـاى افقى طـرح

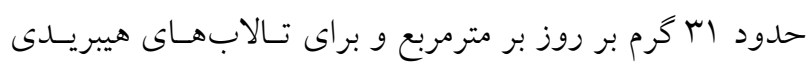

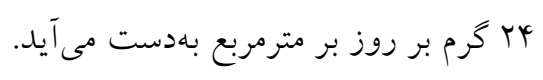

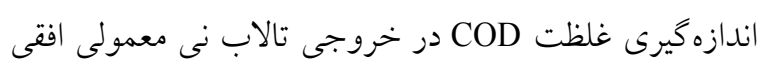

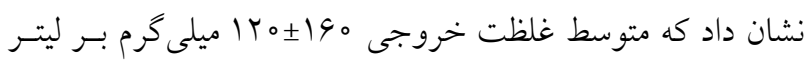




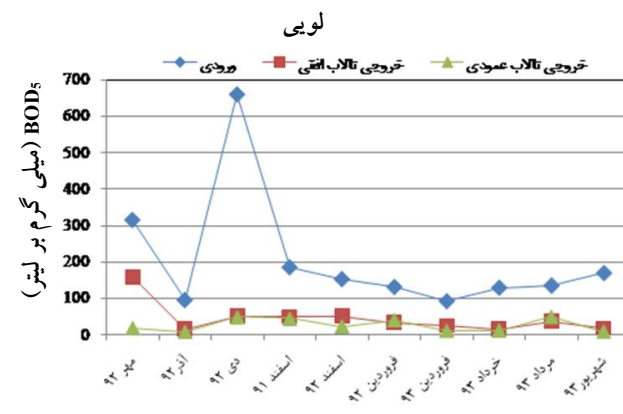

a.
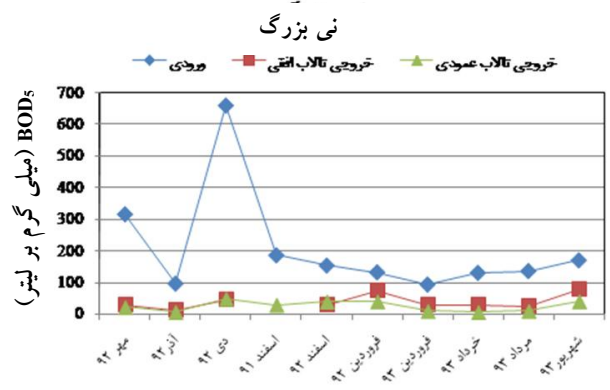

$\alpha$

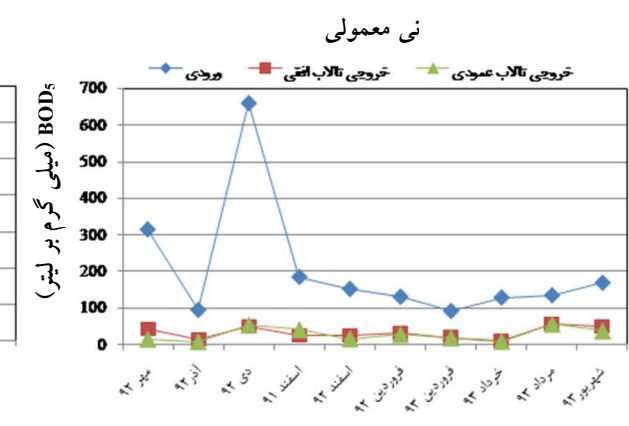

s.

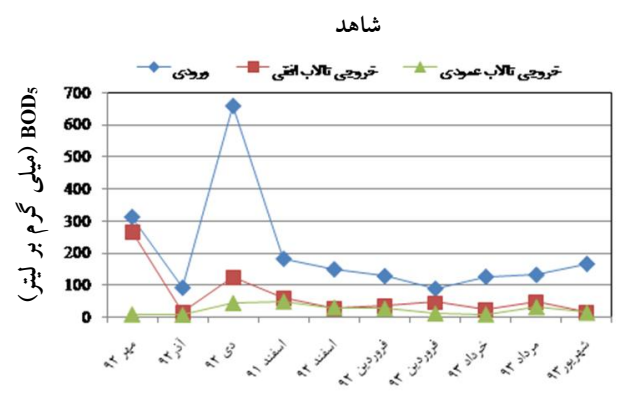

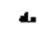

شكل f. مقايسه غلظتهاى هBOD اندازهيرى شده در ورودى و خروجى تالابهاى طرح

براساس اختلاف غلظت هاى ورودى و خروجسى بـه تـالابهـا

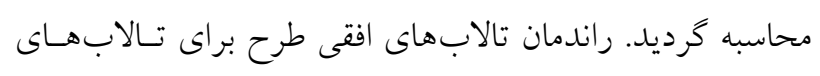

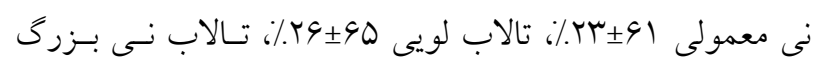

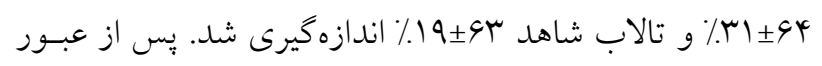

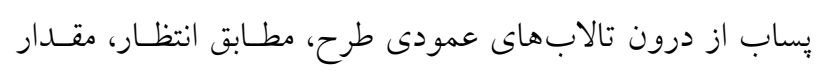

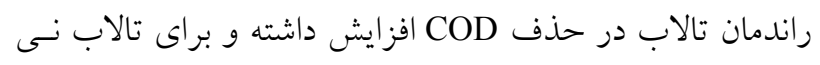

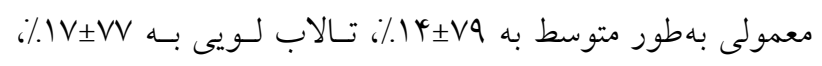

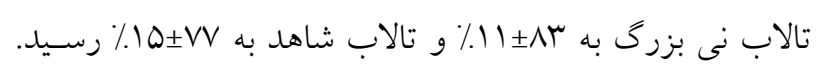

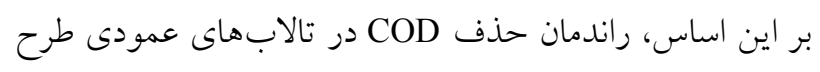

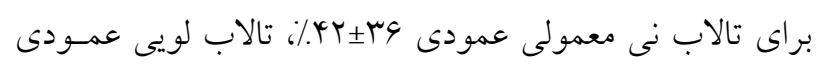

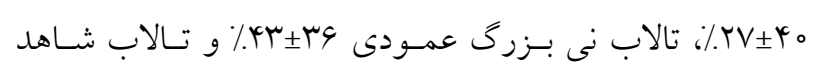

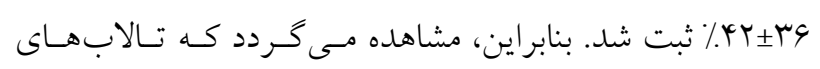

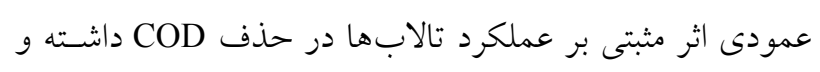

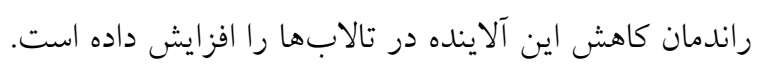

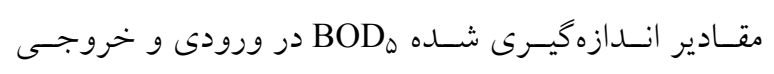

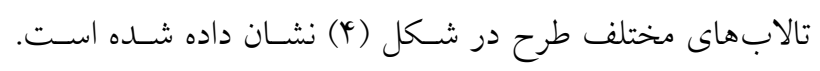

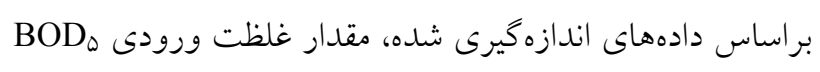

پساب خروجى كاهش بيشترى را نشان داد. بايد متذكر شـد كـهـ

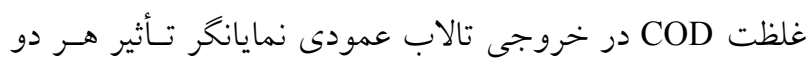

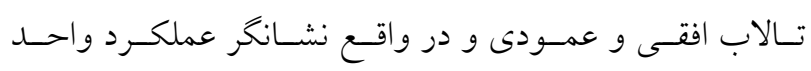

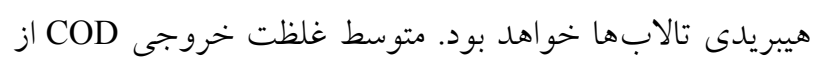

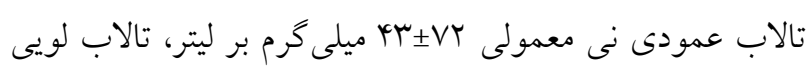

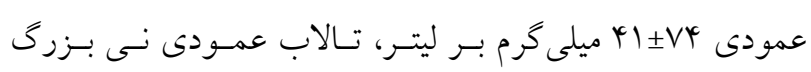
Y०

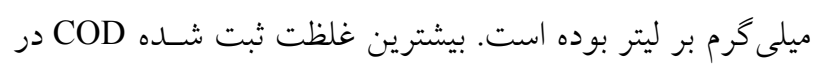

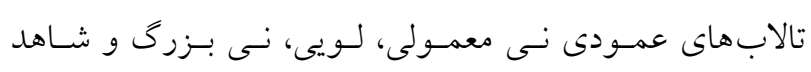

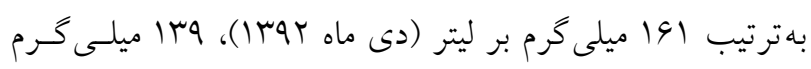

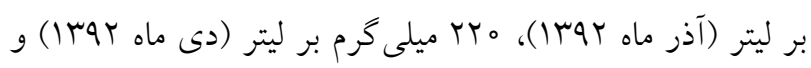

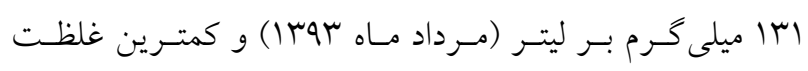

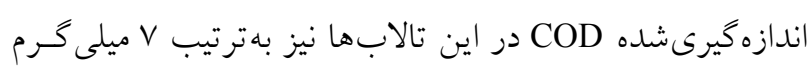

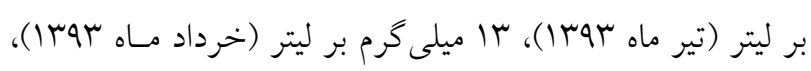

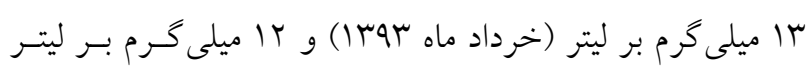

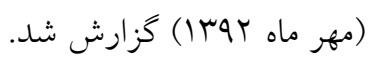

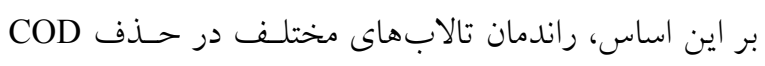


راندمان تالابهاى افقى طرح براساس اختلاف غلظت هـاى

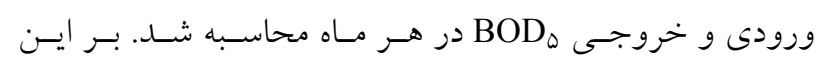

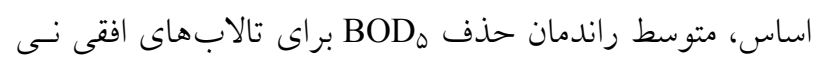

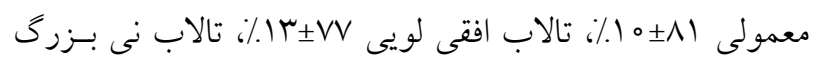

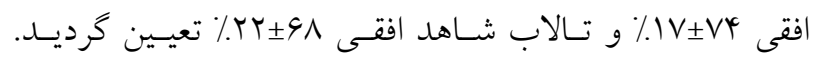
محاسبه راندمان در تالابهاى عمودى طرح نشـان داد كـه ايسن تالابها اثر مثبتى بر راندمان كلى طرح در حذف آلاينده هماند

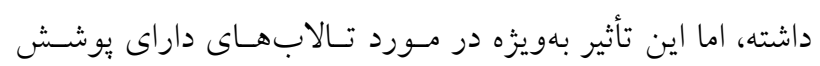

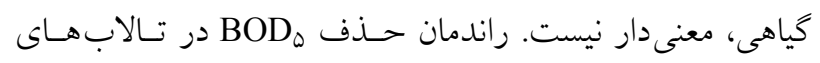

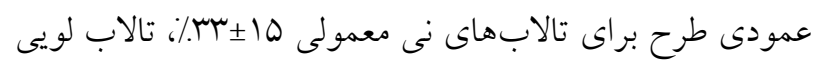

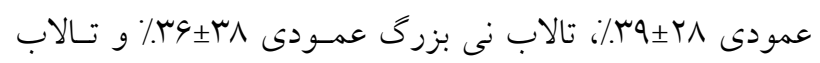

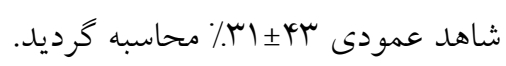

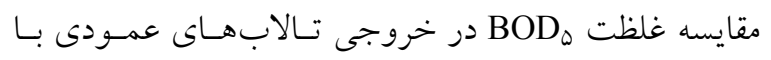
غلظتهاى ورودى به تالابها نشان داد كه متوسط راندمان هـر

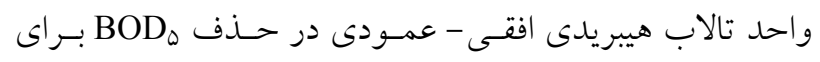

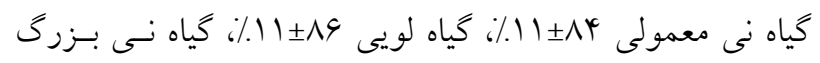

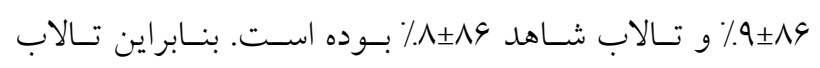

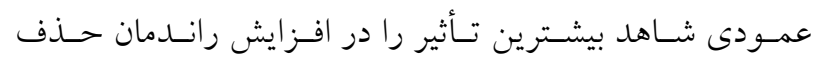
BOD。

بحث

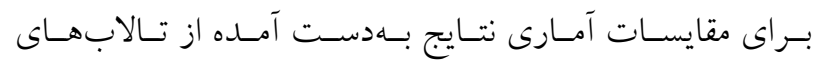

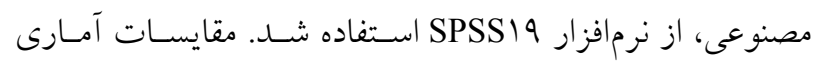

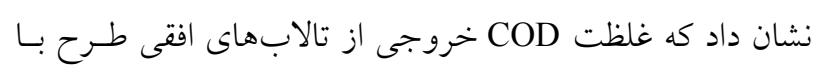

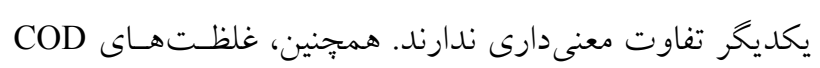

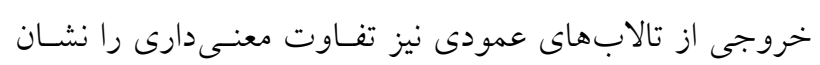

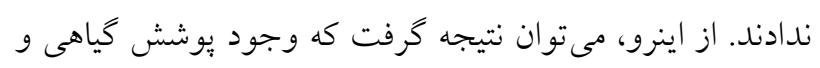

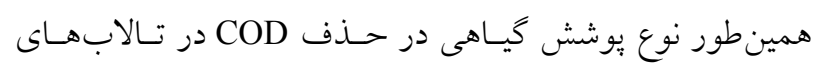

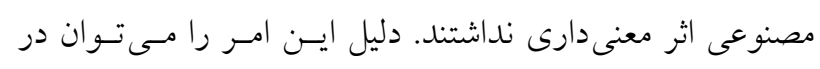

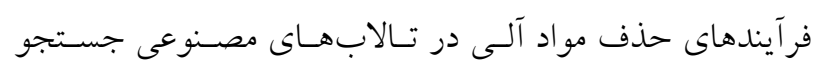

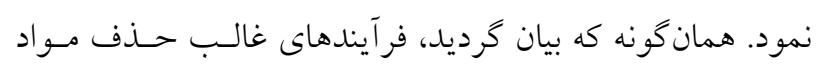
آلى درون محيط تالابهاى مصنوعى شامل فيلتراسيون، ترسيب

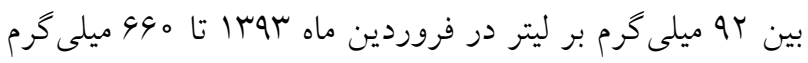

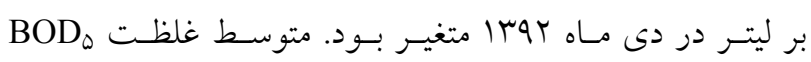

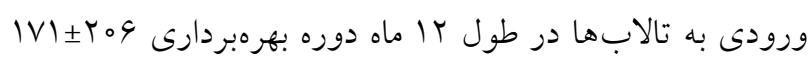
ميلى گرم بر ليتر محاسبه شد. به اين ترتيب، مقــدار بـار آلاينــهـ

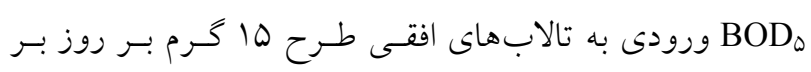

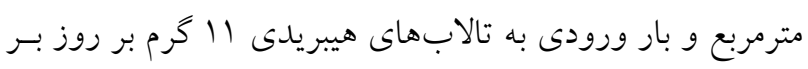
مترمربع اندازه ميرى شد.

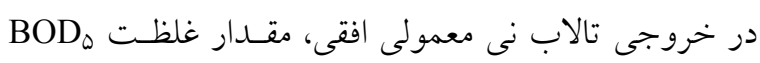

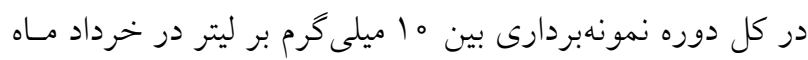

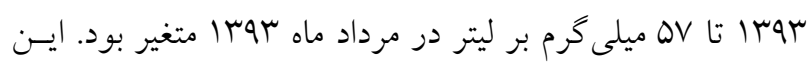

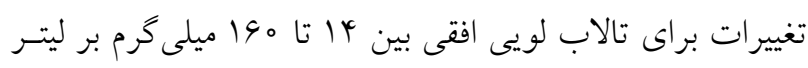

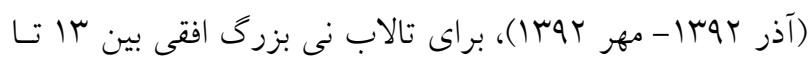

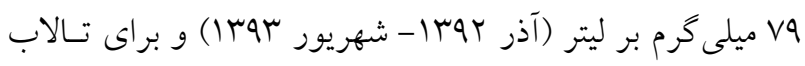

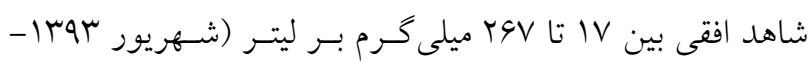

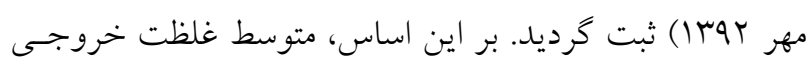

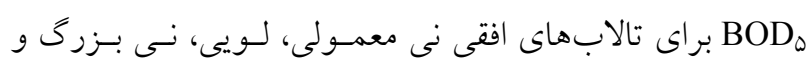

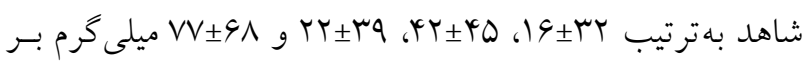
ليتر محاسبه شد.

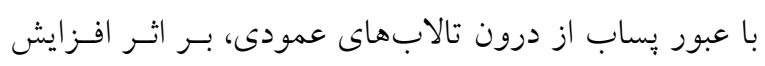

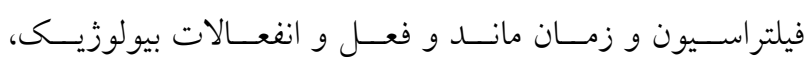

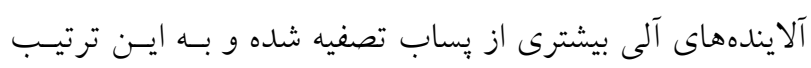

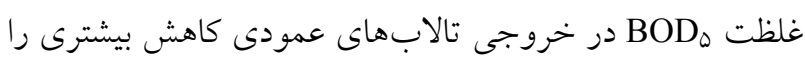

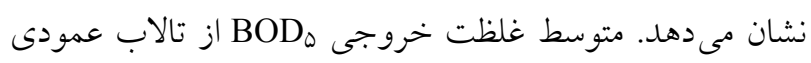

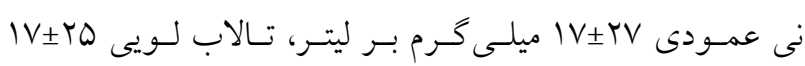

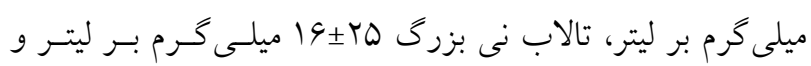

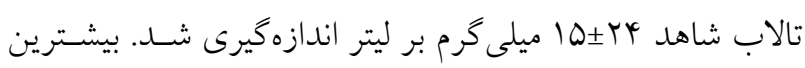

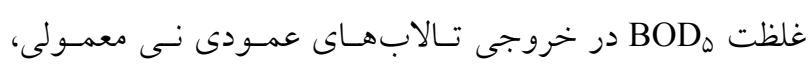

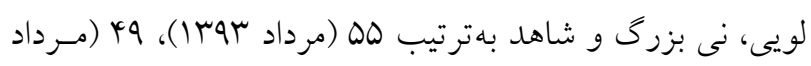

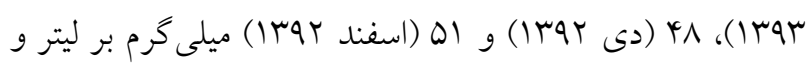

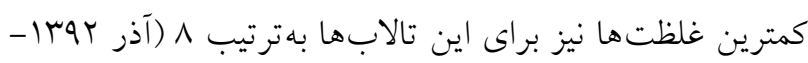

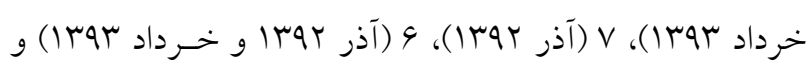

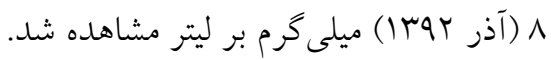


در مورد غلظتهاى BOD جنين تفاوتى مشـاهده نمسى گـردد.

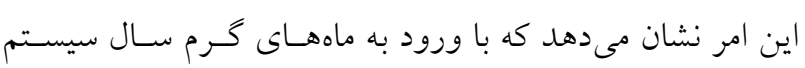

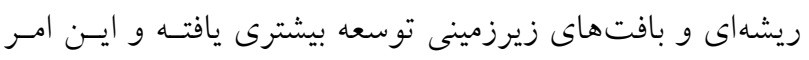

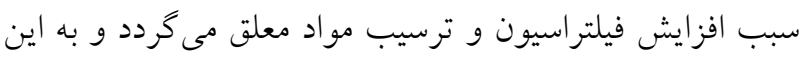

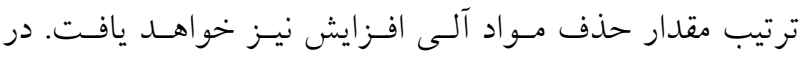

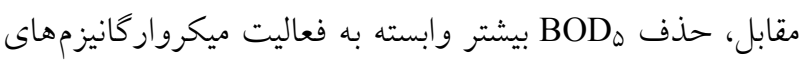
تالاب خواهد بود. جون تالابهاى طرح از نوع زيرسطحى بوده

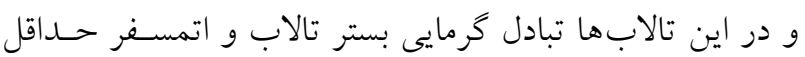

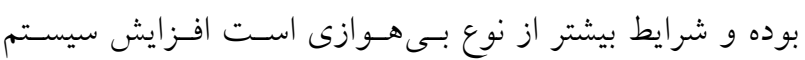

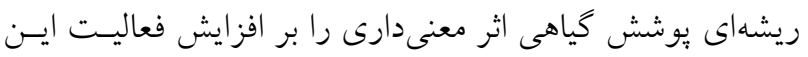
باكترىها نداشته و به اين ترتيب مىتوان بيان نمـود كـه اثـرات

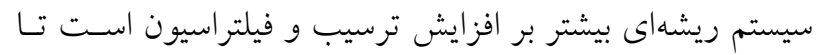
بر افزايش فعاليت ميكرواركانيزمهاى تالابها.

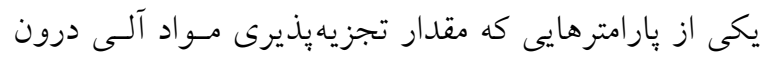

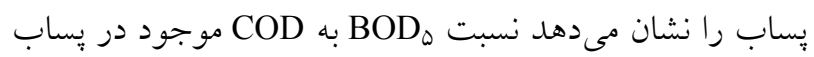

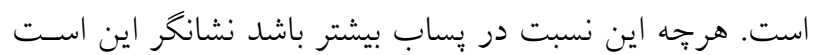

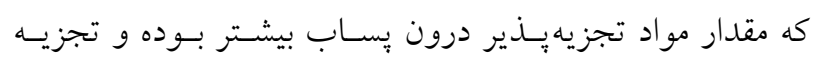

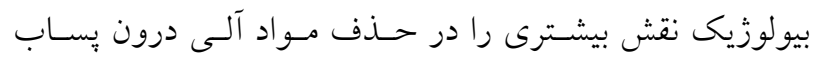

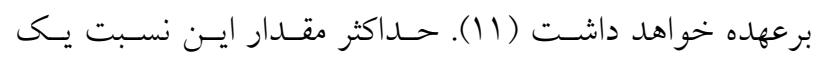

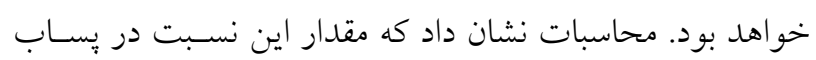

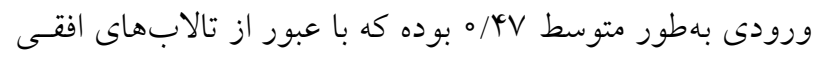

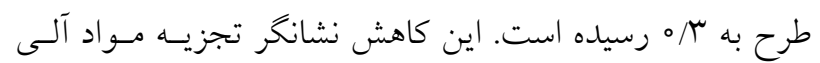

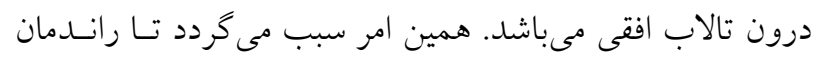

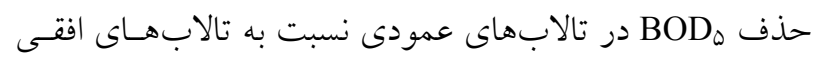
كمتر باشد. رابطه ميان نسبت هOD

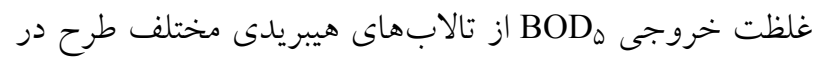

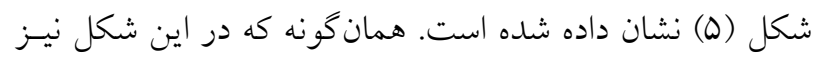

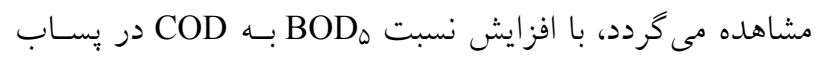

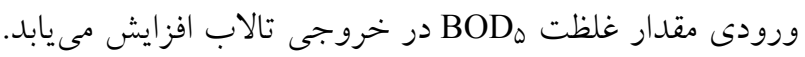

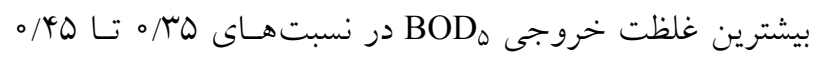

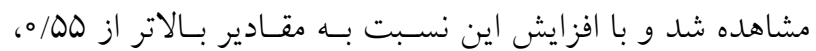

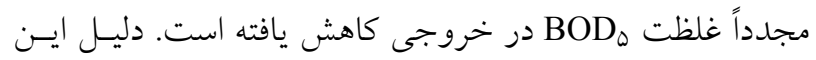

درون محيط متخلخل و تجزيه هوازى و بـىهـوازى مسىباشـند.

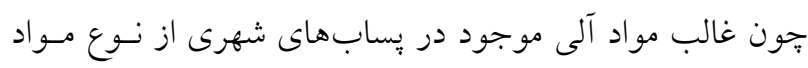

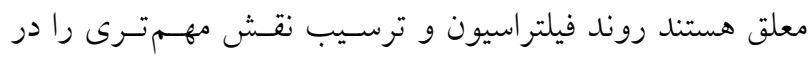
حذف مواد آلى بر عهده خواهند داشت. وجود سيستم زيرزمينى دئن

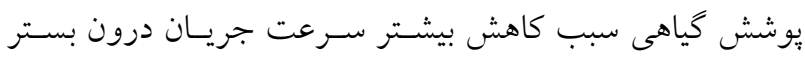

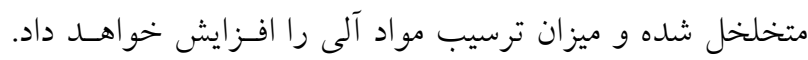

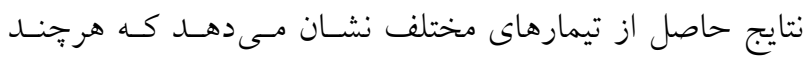

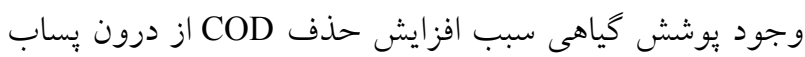

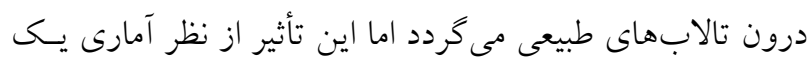

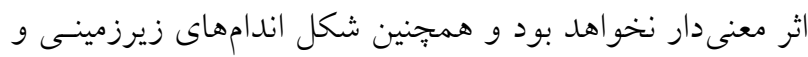
مقدار نفوذ ريشه در حذف COD اثر معنىدارى را نداشت.

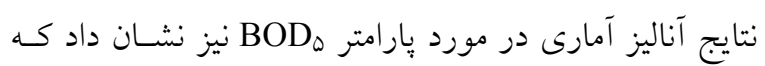
مقدار غلظت خروجى از تالابهاى افقى و عمودى و در نتيجـهـ

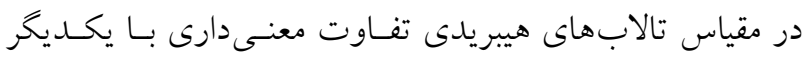

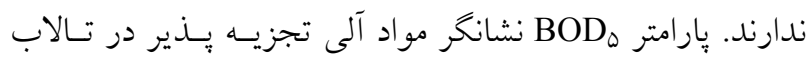
بوده و نشانخر فعاليت باكترىهاى هوازى و بىهوازى در تالاب

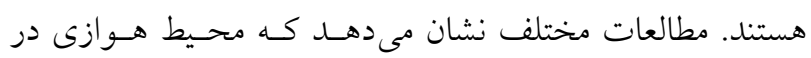

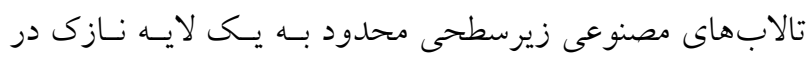

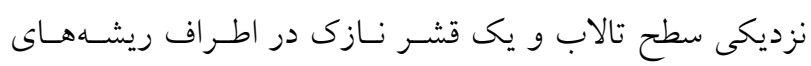

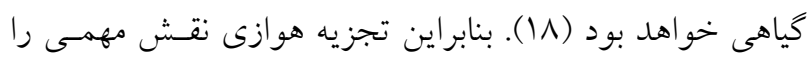

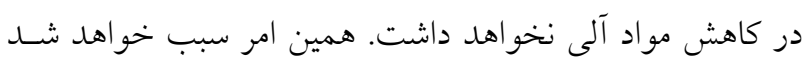

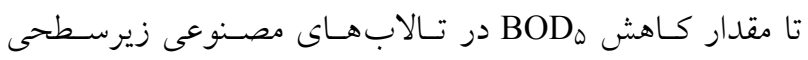

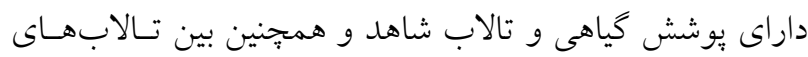

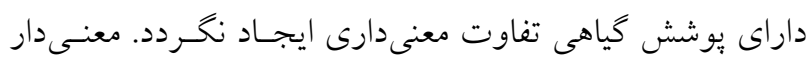

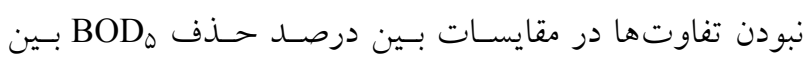

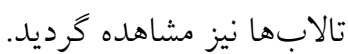

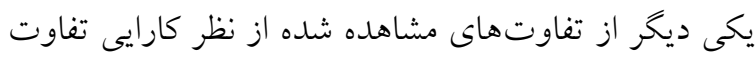

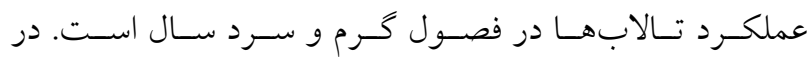
صورتى كه شش ماه مهر تـا اسـفند را فصـل سـرد و شـش مـاه فروردين تا شهريور را فصل گرم سال درنظر بخيريم، مقايسـات

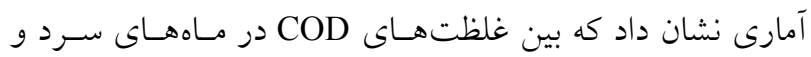
ماههاى گرم سال تفاوت معنى دار مشاهده مى گردد. در حالى كـه. 
افقى كارايى كمترى از ديخر تالابها در حذف BOD قسمت عمودى راندمان بالاترى را نشان داده است.

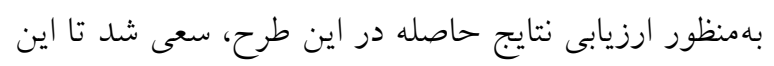

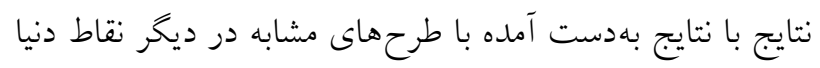

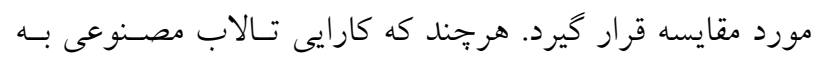

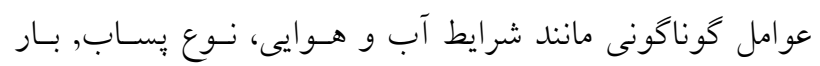

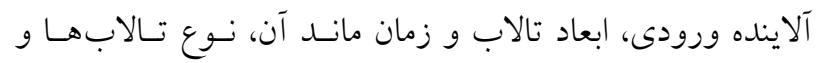

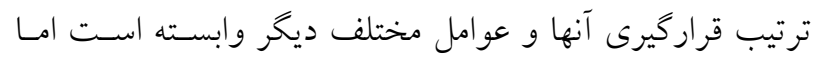

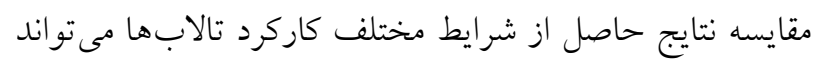

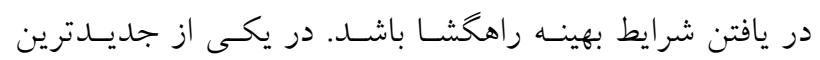

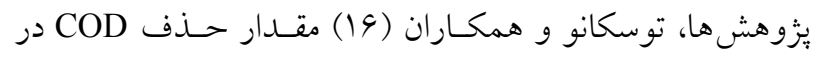

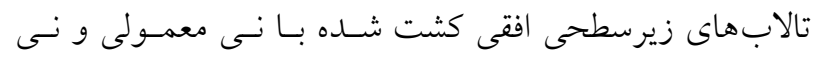

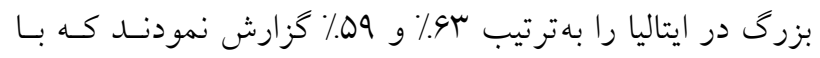
كارايى تالاب هـاى افقـى طـرح مطابقـت كامـل دارد. همجنهـين

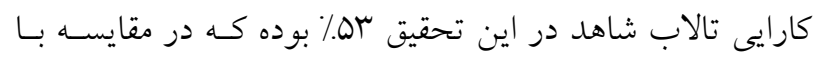

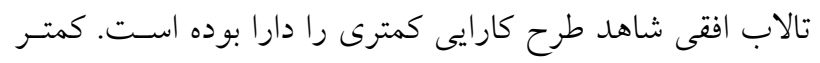

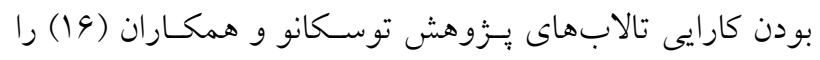

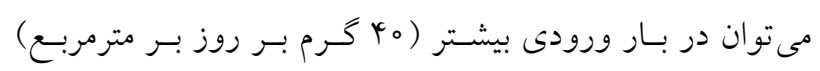

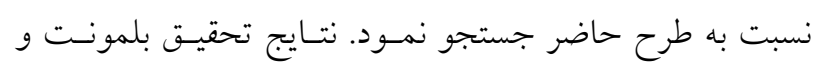

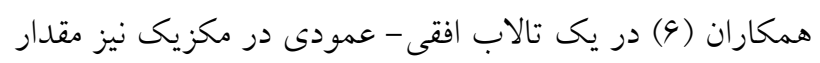

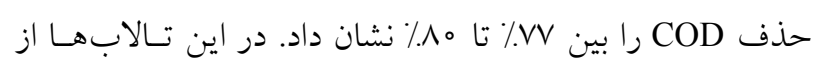

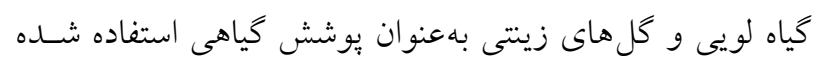

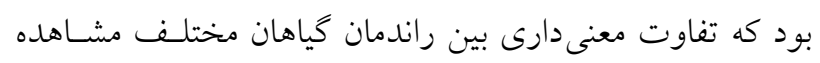

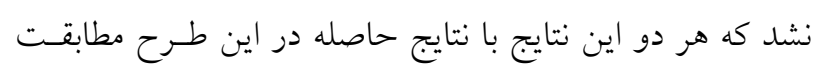
بالايى دارد. - مان.

مطالعـات عبيــى و همكــاران (Y) نشــان داد كـهـ ترتيـب

قرارگيرى تالابهاى هيبر يدى افقى و عمودى تفاوت معنى دارى همي

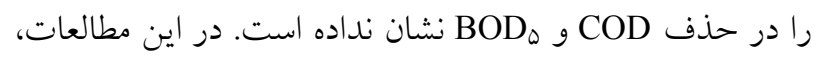
متوسط راندمان حذف همOD از تالابهاى افقى كشت شده بـا

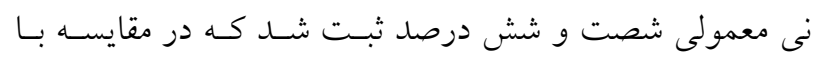

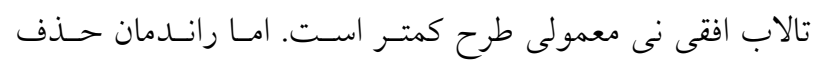

امر شايد اين باشد كه با افزايش مواد آلى تجزيسهـــير، محسيط

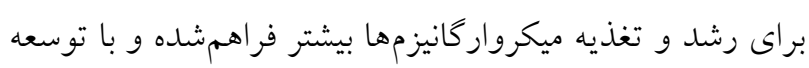

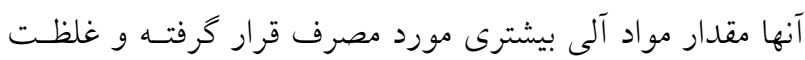

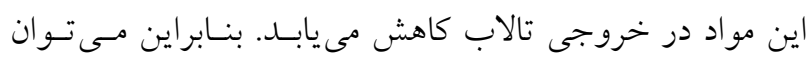

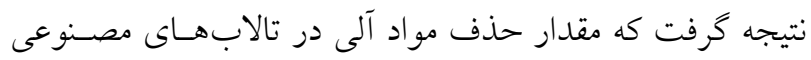

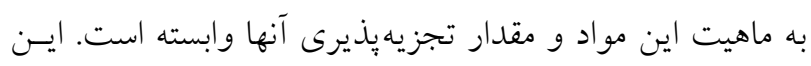

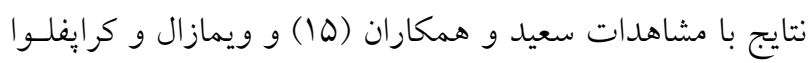

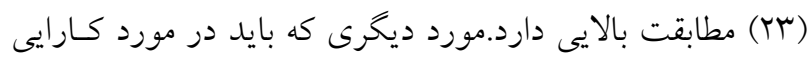

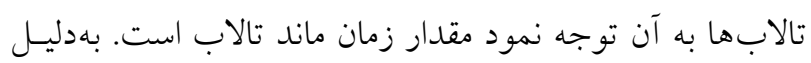

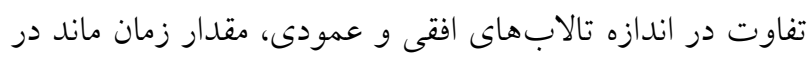

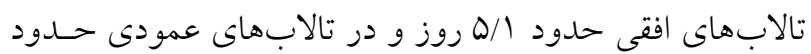

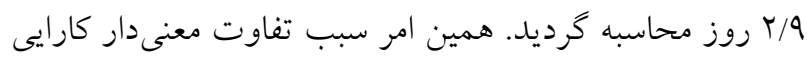

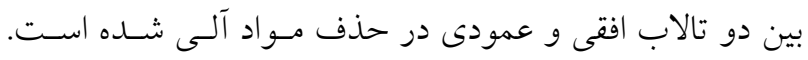

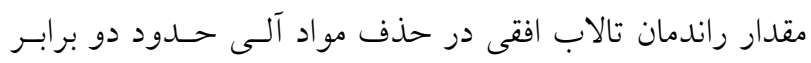

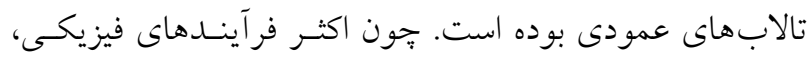

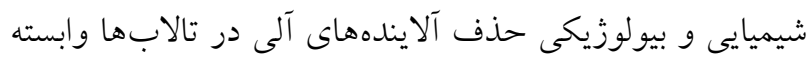

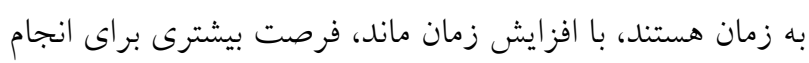

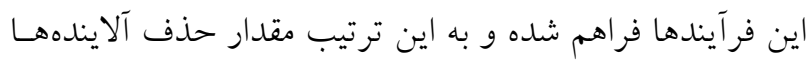

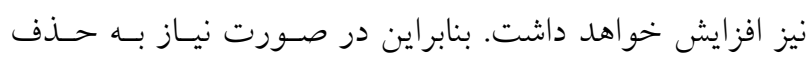

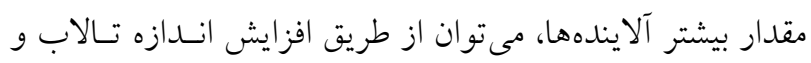

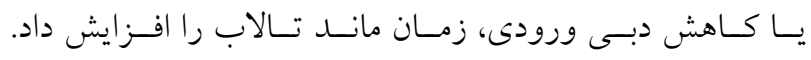

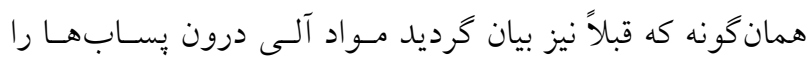

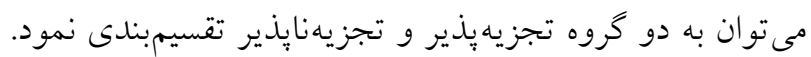

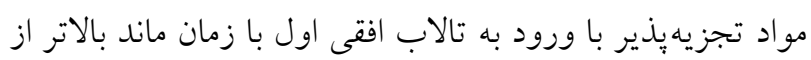

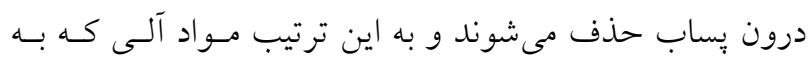

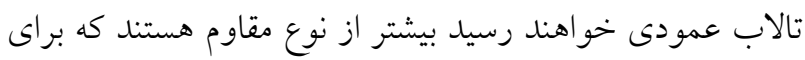

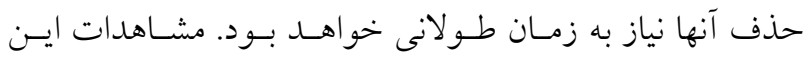

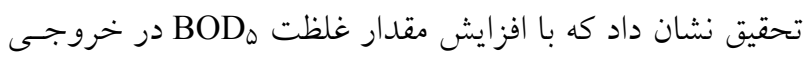

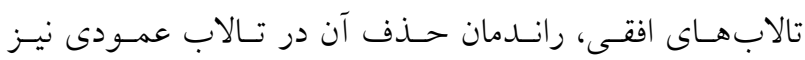

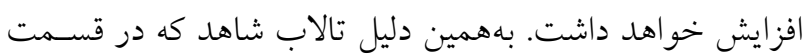


جدول ا. مقايسه ضرايب مدل مرتبه اول هODD محاسبهشده براى تالابهاى طرح

\begin{tabular}{|c|c|c|c|}
\hline \multirow{2}{*}{ 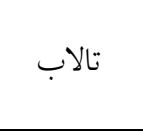 } & \multicolumn{3}{|c|}{ مقدار متوسط ضريب مدل كنتيك مرتبه اول BOD (متر بر سال) } \\
\hline & ت ت الاب هاى افقى & تالابهاى عمودى & تالاب هاى هيبر يدى \\
\hline نى معمولى & $r \varepsilon / r \pm \mid \Delta / \mathcal{F}$ & $\boldsymbol{F} / \mathrm{V} \pm 1 \mathcal{F} / \mathrm{r}$ & $r r / T \pm 19 / T$ \\
\hline 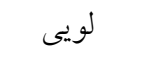 & $r V / r \pm \Lambda$ & $|r / V \pm r| / \mid$ & $r r / V \pm 1 \Delta / r$ \\
\hline 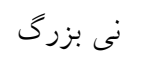 & $r r / r \pm 1 \cdot / q$ & $10 / V \pm 19 / \Lambda$ & $r \Delta \pm 1 f$ \\
\hline شاهد & $r \cdot / 4 \pm q / 9 \Lambda$ & $19 / 0 \pm 19 / 9$ & $r \mid r \pm 1$. \\
\hline
\end{tabular}

شد (r) (I). با بررسى اين تالاب كه متشكل از دو تالاب عمـودى و يك تالاب افقى بود، مشـاهده شـد كـه دبسى ورودى بــه ايـن تالاب V/ مترمكعب بر روز بوده اما سطح كلى ايسن تـالابهـا rr| مترمربع درنظر گرفته شده بود كه اين امر سبب شده بود تا بار ورودى به اين سيستم يكجهارم طرح حاضر گردد.

\section{محاسبه ضريب مدل مرتبه اول} مقدار ضريب مدل كنتيك مرتبـهـ اول براسـاس دبسى ورودى بـه

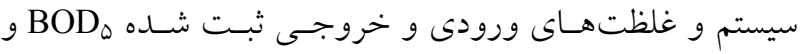
COD كرديد (جدول (). براى آلاينده مOD BOD مقـدار متوسـط ضـريب مدل كتتيك مرتبه اول براسـاس دبسى ورودى بـه هـر تـالاب و غلظتهـاى ورودى و خروجسى در مـاههـاى مختلـف محاسـبه كرديده و نتـايج در قالـب جــدول ( (1) نشـان داده شـده اسـت. همان كونه كه مشاهده مى گردد در مقيـاس تـالاب افقى مقـدار ضريب در تالاب نى معمولى بالاتر از ديخـر تـالابهـاى طـرح

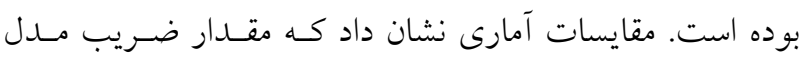
مرتبه اول در تالاب افقى نى معمولى در سطح ه درصد اختلاف معنى دار با تالاب شـاهد دارد. همجزنسين در صـورت اسـتفاده از آزمون LSD براى مقايسه ميانخينها، مقدار متوسط ضـريب در تالاب نى معمولى با تالاب هاى لويى و نى بـومى نيـز اخـتلاف معنى دار خواهند داشت. عكس روند فـوق در مـورد تـالابهـاى عمـودى مشـاهده مى گردد. به اين ترتيب كه مقدار ضريب مدل براى تالاب شاهد بالاترين مقدار و براى تالاب نى معمولى كمتـرين مقــدار را دارا
تالاب افقى حدود ينجاه و هشت درصد بود كه بسيار بـهـ COD راندمان تالاب طرح نزديك مىباشد. هم:جنـين در ايسن تحقيـق، مقدار راندمان حذف COD و شده با لويى به ترتيب بيست و ينج درصد و ينجاه درصــ بـوده كه بهترتيب كمتر و بيشتر از تـالاب عمـودى لـويى طـرح بـوده است. مقدار حذف COD و BOD در تالاب هيبريدى متشـل از يك تالاب عمودى، يك تالاب افقى و يك تالاب سـطحى در اسيانيا بهترتيب هم و وqه درصد گزارش شد (ه). بار ورودى بـه اين تالابها 9 كرم هOD بر مترمربع بر روز بوده كـه كمتـر از

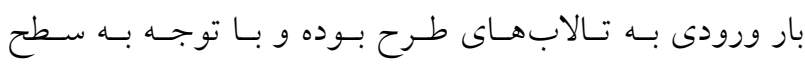
تالابهاى مذكور كه بيش از وبرابر تـالابهـاى طرح حاضـر بوده و بيشتر بودن زمان ماند، بالاتر بودن راندمان اين تسالابهـا را مى توان توجيه نمود. كامينو و همكاران (V) مقدار حداكثر حذف COD و مOD در يك تالاب هيبريدى عمودى- افقى در ايتاليا كه بـا كيـاه نـى

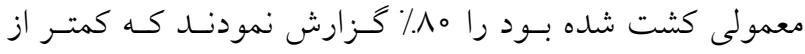
حداكثر راندمانهاى دست يافتـه در ايسن طـرح اسـت. بيشـترين راندمان حذف COD و اين طرح بهترتيب 91\% (تير ماه سوب1) و 99\% (مهر مـاه rar) اندازه كيـرى شـــ. در تحقيـق ويمـازال و كرايفلـوا (19) مقــدار متوسط حـذف COD و BOD در يـك تـالاب هيبريـدى ســ

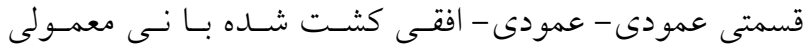

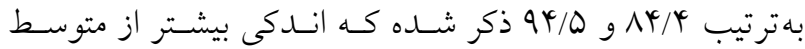
درصد حذف اين آلايندههـا در طـرح حاضـر مسىباشـد. مقـدار حذف ه BOD در يك تالاب هيبريدى در استونى 191\% خـارش 
جدول r. مقايسه ضرايب مدل مرتبه اول COD محاسبهشده براى تالابهاى طرح

\begin{tabular}{|c|c|c|c|}
\hline \multirow{2}{*}{ 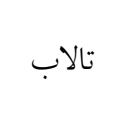 } & \multicolumn{3}{|c|}{ مقدار متوسط ضريب مدل كنتيك مرتبه اول COD (متر بر سال) } \\
\hline & تالابهاى افقى & تالاب هاى عمودى & تالابهاى هيبر يدى \\
\hline نى معمولى & $r F \pm I r / F$ & $\varphi q / \Gamma \pm V Y / \mathcal{F}$ & $r / / \pm r \cdot / V$ \\
\hline 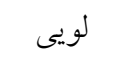 & $r N / \Delta \pm 19 / \Delta$ & $\Delta \cdot \pm F F / r$ & $r 9 / 0 \pm 19 / 9$ \\
\hline 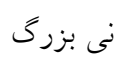 & $r M \pm r r / l$ & $\Delta 1 \pm 91$ & $r r / V \pm I Y / r$ \\
\hline شاهد & $r V / \Delta \pm I r$ & $\Delta q / \boldsymbol{r} \pm V \mathcal{F} / \mathcal{F}$ & $r q / r \pm 1 \wedge / \Delta$ \\
\hline
\end{tabular}

تالابهاى افقى يا عمودى هستند. آناليز آمارى ضر ايب محاسـبه شده نشان داد كه در سطح ه درصد هـيج اخـتلاف معنسدارى بين تالابهاى افقى، تالابهاى عمودى و تالابهاى هيبريـدى مشاهلده نشد. مقدار ضريب مدل كنتيـك مرتبـه اول BODV بـراى تـالاب هيبريدى عمودى - عمودى- افقى در استونى / ب متر بر سـال

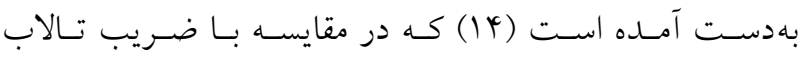
هيبريدى نى معمولى طرح كمتر بـوده اسـت. همجنـين در ايسن مطالعه بين ضرايب محاسبه شده در فصـول گـرم و سـرد سـال تفاوت معنى دارى مشاهده نشد كه اين امر بـا نتـايج حاصـله در اين طرح مطابقت دارد. زوريتا و همكاران (YY) مقـدار ضـريب

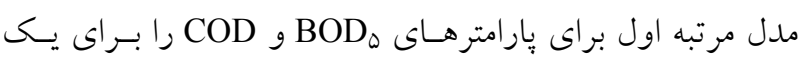

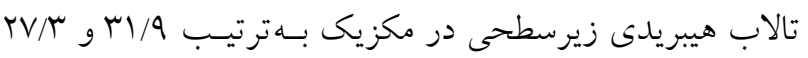
بهدست آوردند كه با نتايج اين طرح كاملاً مطابقت دارد.

قابليت بازيافت پِاب تصفيهشده از نظر غلظت مواد آلى همان كونه كه بيان گرديد، رشد جمعيت و افزايش مصـارف آب و همجينين كاهش منابع آب شيرين و پياك موجود سبب شده تـا

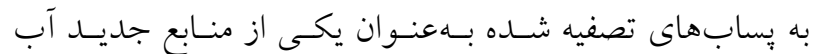
نخريسته شود. بازيافت يسابها علاوه بر برطـرف نمـودن نيـاز آبى بخش هاى مختلف و كاهش فشار بر منابع آبهاى سـطى بـ و زيرزمينى، خطرات رها سازى آنهـا در محسيط زيستـ را نيـز كاهش خواهد داد. براى استفاده از بِــابهــاى تصـفيهشــده در مصارف گوناگون، غلظت آلايندها در آنها بايد بـه زيـر حسـدود استاندارد مورد نياز در آن مصرف برسد. دسـور العمل "ضـوابط
بوده است. دليل اين امر بالاتر بـودن غلظـت BOD مرودىى بـه تالاب عمودى شاهد در مقايسه بـا ديخـــ تـالابهـاى عمـودى بهويزه تالاب نـى معمـولى اسـت. البتـهـ از نظـر آمـارى مقــادير ضريب محاسبه شده براى تالابهاى عمودى با يكديخر تفاوت معنى دار نداشتند. مقايسه ضرايب مربوط به تالاب هاى هيبريدى نشان مىدهد كه مقدار اين ضرايب بـراى تـالابهــاى مختلـف بسيار به يكديخر نزديك شده و اختلاف معنى دارى بين عملكرد تالابهاى مختلف مشاهده نمى گردد. ايسن امـر مزيست بوشـش

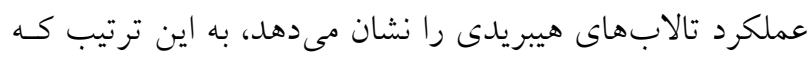

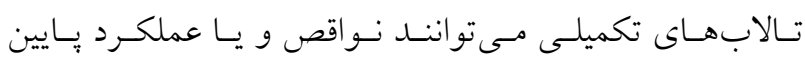
تالابهاى قبلى را جبران نموده و عملكرد كل سيستم را به يك مقدار قابل قبول ارتقاء دهند.

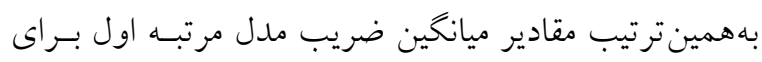
آلاينده COD براى تـالابهـاى مختلـف طـرح در جـدول (r) نمايش داده شده است. در مورد COD در ميان تالابهاى افقى، تالاب شاهد بالاترين مقدار و تـالاب نـى معمـولى بــايين تـرين مقدار ضريب مدل مرتبه كنتيك را بهخود اختصاص دادهاند. اين روند در مورد تالابهاى عمودى معكـوس بــوده و تـالاب نسى معمولى در مقايسه با ديخر تالابـهاى عمـودى بيشـترين مقـدار ضريب مدل كنتيك را دارا بود كـه ايـن امـر بـه غلظـت بـالاتر ورودى COD بــه ايـن تـالاب مربـوط مسىباشـــ در مقيـاس تالابهاى هيبريدى نيز مقادير ضرايب مـدل كتتيـى بسـيار بـهـ يكـديخر نزديـك بـوده و اختلافــات مشــاهده شــده در مـورد تالابهاى عمودى و افقى با كاهش روبرو بوده است كه اين امر دليلى ديخر بر عملكرد بايدار تالابهاى هيبريدى در مقايسه بـا 
براساس استانداردهاى آيين نامه، غلظت بيشـينه COD بـراى

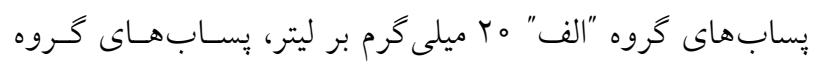

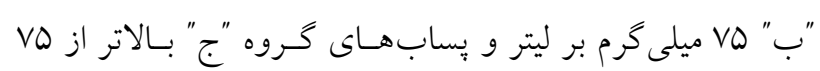

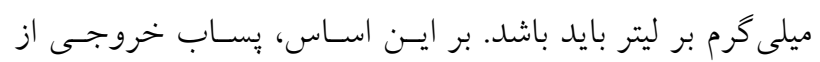

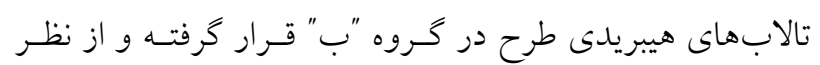

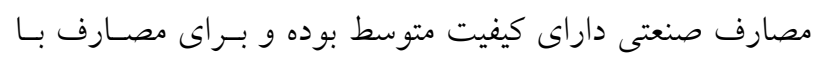

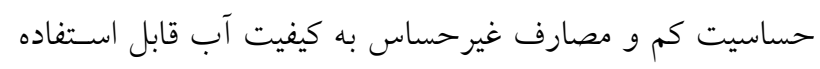
است. براى مصارف بسيار حساس صنعتى نياز به تصـفيه بيشـتر

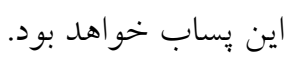

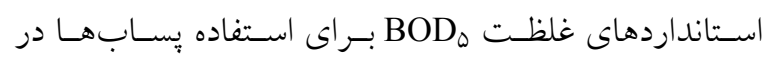

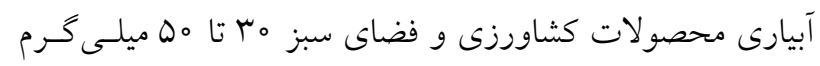

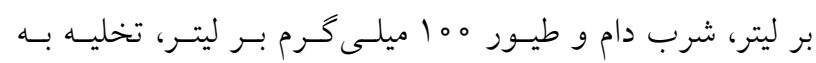

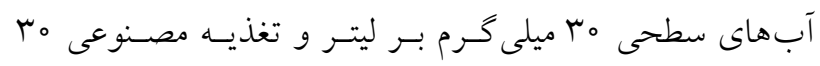

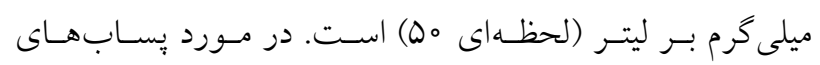

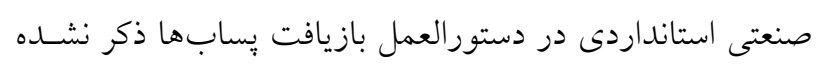

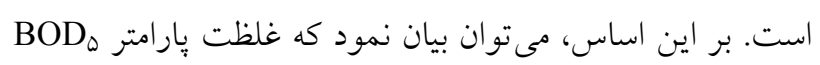

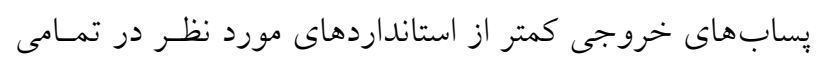

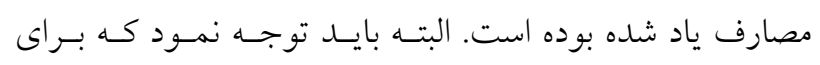

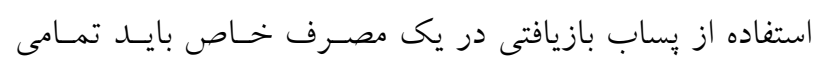

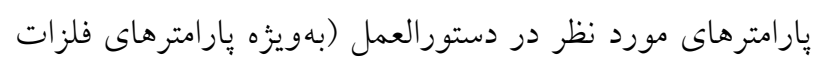

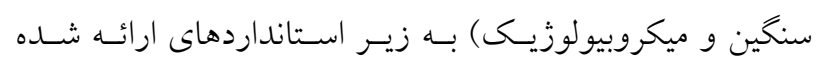

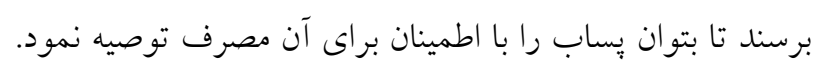

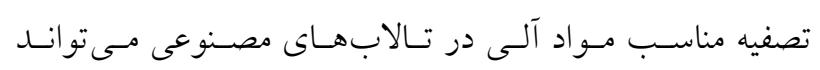

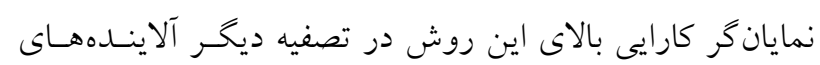

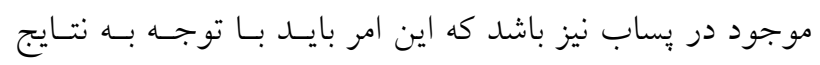

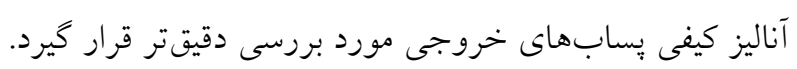

\section{نتيجه گيرى}

تالابهاى مصنوعى يكى از فناورىهـاى نسـبتاً جديــ تصـفيه

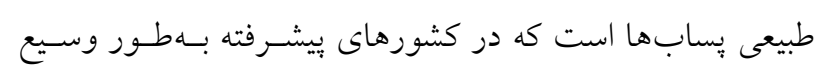

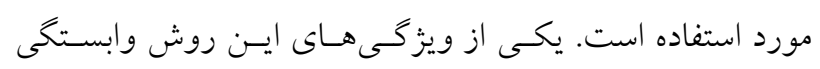

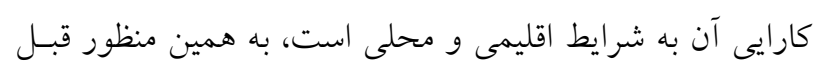

زيست محيطى استفاده مجدد از آبهاى بركشتى و يسـابهـا

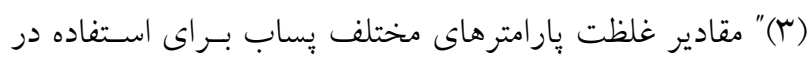

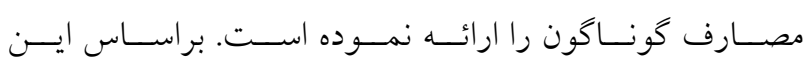

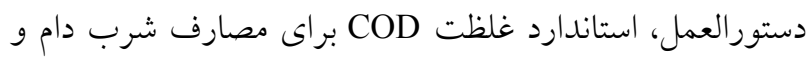

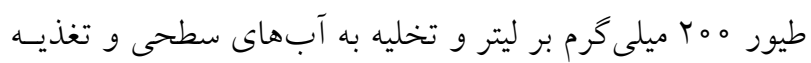

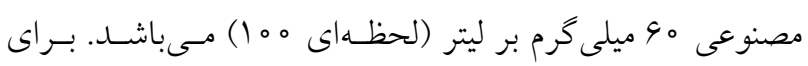

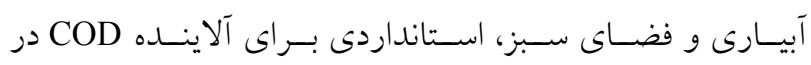

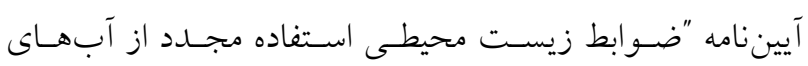

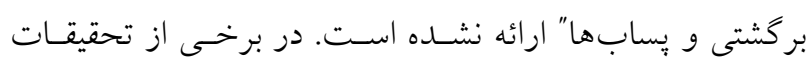

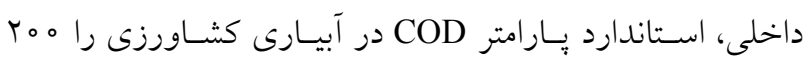

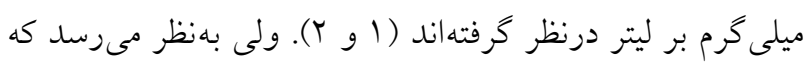

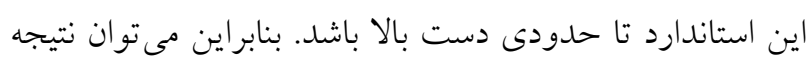

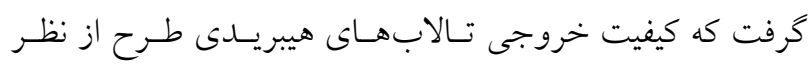

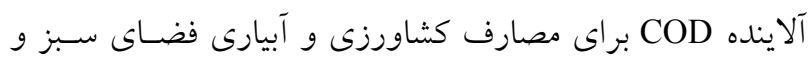
شرب دام و طيور بلامانع بوده و براى مصارف تخليسه بـه درون آب هاى سطحى و تغذيسه مصـنوعى تنهـا در فصـل خـرم سـال

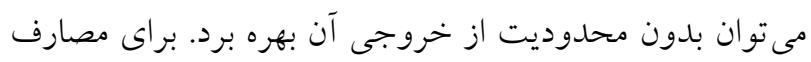

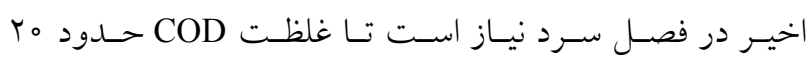
ميلى گرم بر ليتر كاهش يابد.

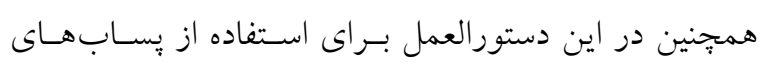

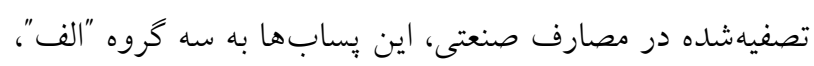

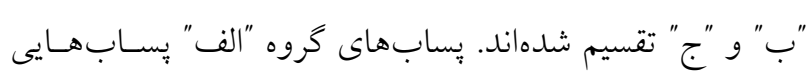

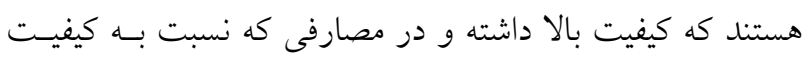

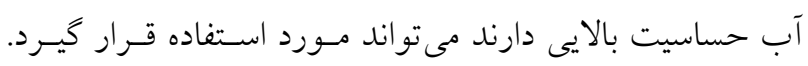

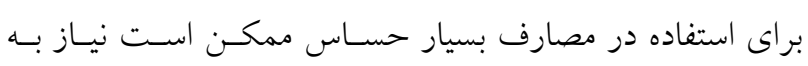

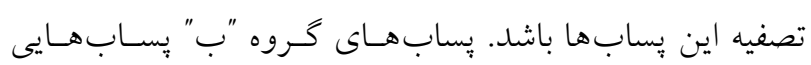

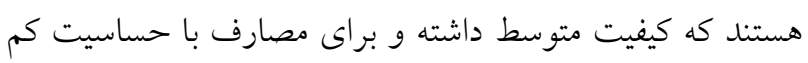

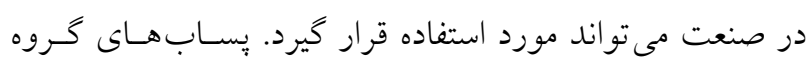

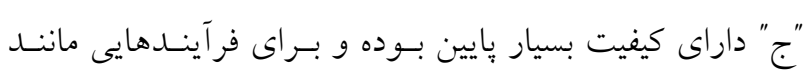

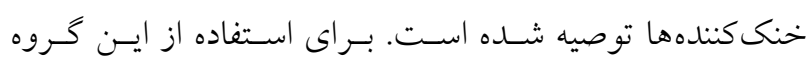
يسابها در مصارف حساستر نياز به تصفيه مجلد آنها خواهـــ 
COD در تالابهاى مختلف با مقدار حذف BOD

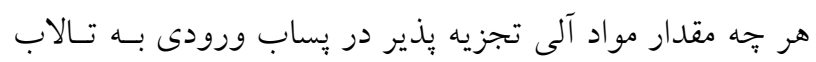

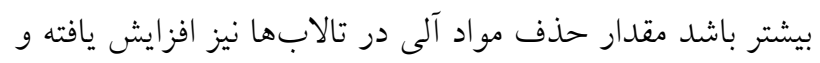

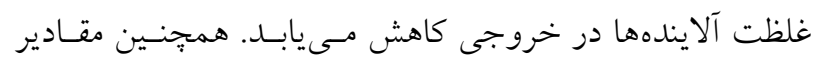

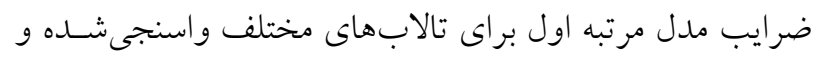

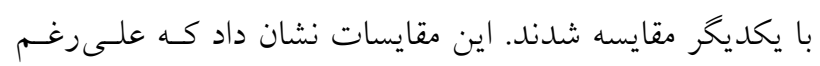

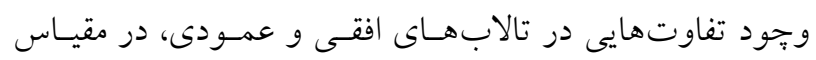

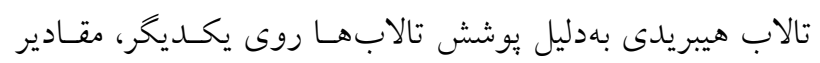

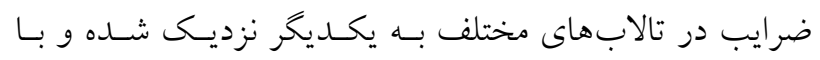

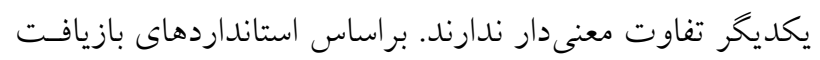

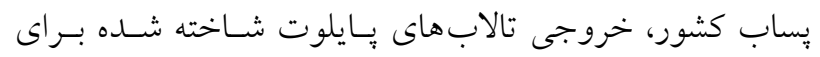

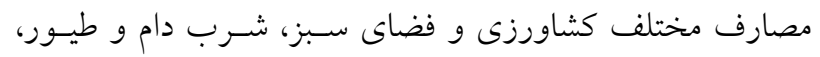

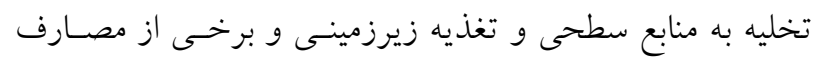

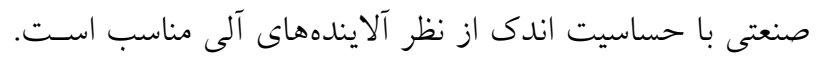

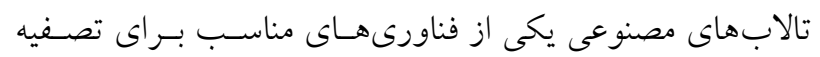

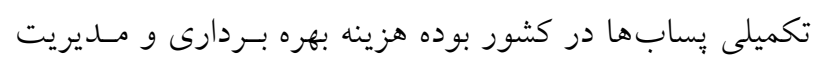

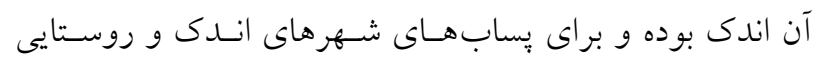
قابل كسترش است.
از كاربرد ايـن طـرحهــا در مقيـاس اصـلى بايســــــــا استفاده از

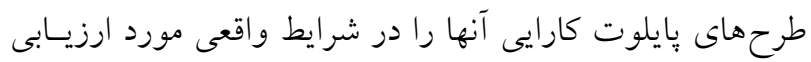

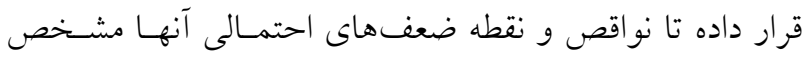

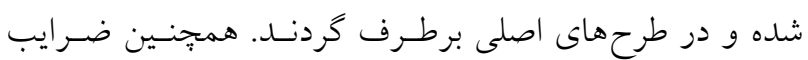

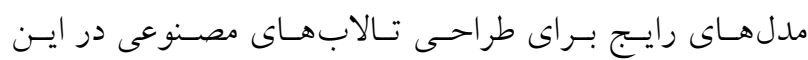

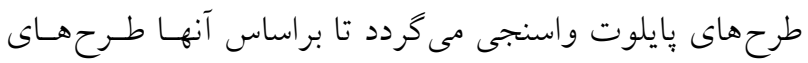

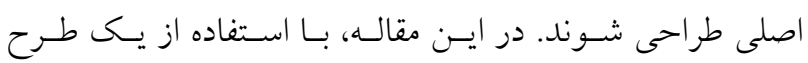

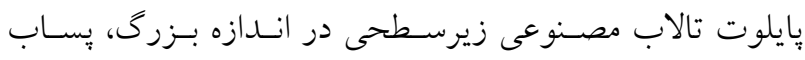

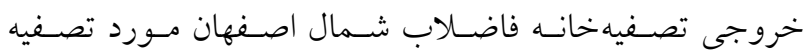

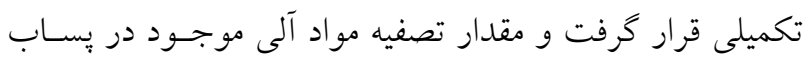

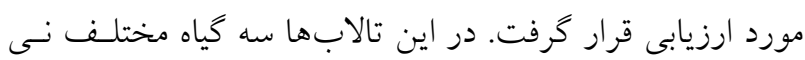

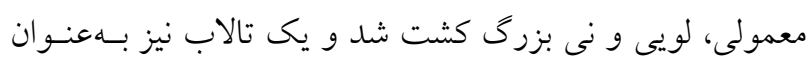
شاهد بدون كشت درنظر كرفته شد.

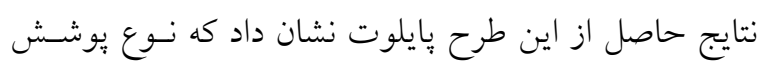

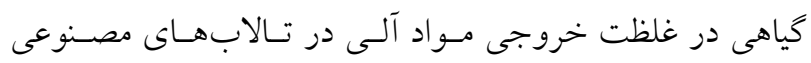

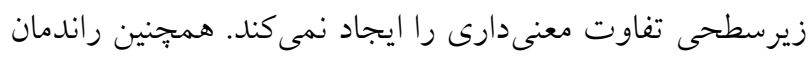

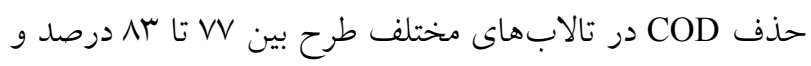
مقدار حذف ه

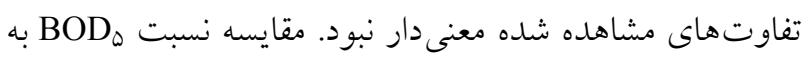

\section{منابع مورد استفاده}

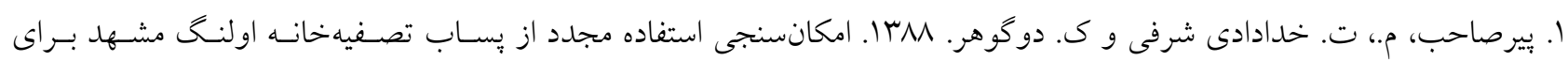

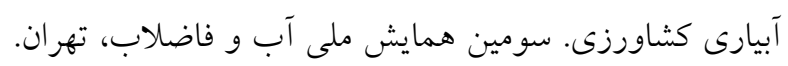

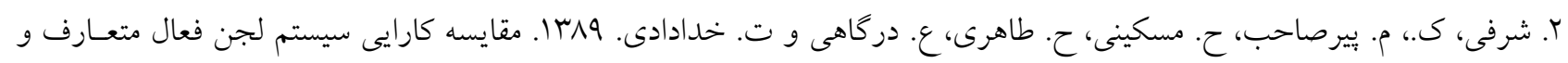

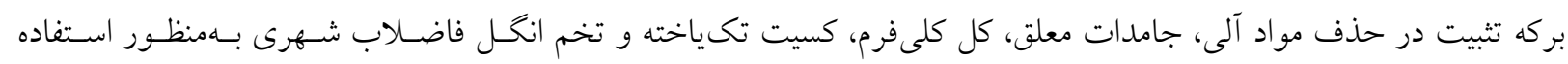

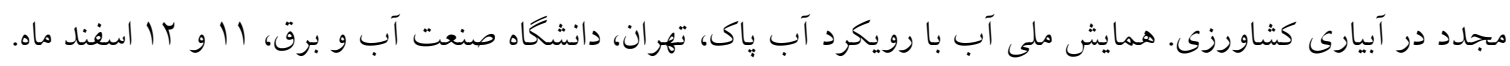

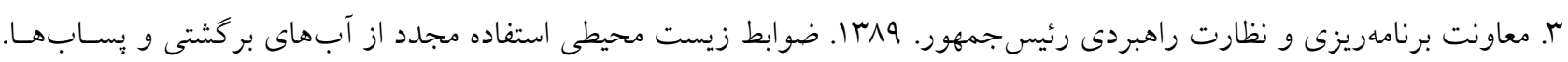

$$
\text { نشريه شماره هاهه. }
$$

4. Abidi, S., H. Kallali, N. Jedidi, O. Bouzaiane and A. Hassen. 2009. Comparative pilot study of the performances of two constructed wetland wastewater treatment hybrid systems. Desalination 246: 370-377.

5. Avila, C., J. J. Salas, I. Martin, C. Aragon and J. Garcia. 2013. Integrated treatment of combined sewer wastewater and stormwater in a hybrid constructed wetland system in southern Spain and its further reuse. Ecol. Eng. 50: 1320.

6. Belmont, M. A., E. Cantellano, S. Thompson, M. Williamson, A. Sanchez and C. D. Metcalfe. 2004. Treatment of domestic wastewater in a pilot-scale natural treatment system in central Mexico. Ecol. Eng. 23: 299-311. 
7. Comino, E., V. Riggio and M. Rosso. 2011. Mountain cheese factory wastewater treatment with the use of a hybrid constructed wetland. Ecological Eng. 37: 1673-1680.

8. Calheiros, C. S. C., P. V. B. Quitério, G. Silva, L. F. C. Crispim, H. Brix, S. C. Moura and P. M. L. Castro. 2012. Use of constructed wetland systems with Arundo and Sarcocornia for polishing high salinity tannery wastewater. J. Environ. Manage. 95: 66-71.

9. Haghshenas-Adarmanabadi, A., M. Heidarpour and S. Tarkesh-Esfahani. 2016. Evaluation of Horizontal-Vertical subsurface hybrid constructed wetlands for tertiary treatment of conventional treatment facilities effluents in developing countries. Water, Air \& Soil Pollut. 227(1): 1-18.

10. Idris, S. M., P. L. Jones, S. A. Salzman, G. Croatto and G. Allinson. 2012. Evaluation of the giant reed (Arundo donax) in horizontal subsurface flow wetlands for the treatment of dairy processing factory wastewater. Environ. Sci. Pollut. Res. 19: 3525-3537.

11. Justin, M. Z., D. Vrhovsek, A. Stuhlbacher and T. G. Bulc. 2009. Treatment of wastewater in hybrid constructed wetland from the production of vinegar and packaging of detergents. Desalination 246: 100-109.

12. Kadlec, R. H. 2009. Comparison of free water and horizontal subsurface treatment wetlands. Ecol. Eng. 35: 159174.

13. Masi, F. and N. Martinuzzi. 2007. Constructed wetlands for the Mediterranean countries: hybrid systems for water reuse and sustainable sanitation. Desalination 215: 44-55.

14. Oovel, M., A. Tooming, T. Mauring and U. Mander. 2007. Schoolhouse wastewater purification in a LWA-filled hybrid constructed wetland in Estonia. Ecol. Eng. 29: 17-26.

15. Saeed, T., R. Afrin, A. Al Muyeed and G. Sun. 2012. Treatment of tannery wastewater in a pilot-scale hybrid constructed wetland system in Bangladesh. Chemosphere 88: 1065-1073.

16. Toscano, A., A. Marzo, M. Milani, G. L. Cirelli and S. Barbagallo. 2015. Comparison of removal efficiencies in Mediterranean pilot constructed wetlands vegetated with different plant species. Ecol. Eng. 75: 155-160.

17. Vymazal, J. 2002. The use of sub-surface constructed wetlands for wastewater treatment in the Czech Republic: 10 years experience. Ecol. Eng. 18: 633-646.

18. Vymazal, J. 2005. Horizontal sub-surface flow and hybrid constructed wetlands systems for wastewater treatment. Ecol. Eng. 25: 478-490.

19. Vymazal, J. 2009. The use constructed wetlands with horizontal sub-surface flow for various types of wastewater. Ecol. Eng. 35: 1-17.

20. Vymazal, J. 2011. Plants used in constructed wetlands with horizontal subsurface flow: a review. Hydrobiologia. 674: 133-156.

21. Vymazal, J. 2013. The use of hybrid constructed wetlands for wastewater treatment with special attention to nitrogen removal: A review of a recent development. Water Res. 47: 4795-4811.

22. Vymazal, J. and L. Kröpfelová. 2009. Removal of organics in constructed wetlands with horizontal sub-surface flow: A review of the field experience. Sci. Total Environ. 407: 3911-3922.

23. Vymazal, J. and L. Kröpfelová. 2011. A three-stage experimental constructed wetland for treatment of domestic sewage: First 2 years of operation. Ecol. Eng. 37: 90-98.

24. Zurita, F., J. De Anda and M. A. Belmont. 2009. Treatment of domestic wastewater and production of commercial flowers in vertical and horizontal subsurface-flow constructed wetlands. Ecol. Eng. 35: 861-869. 


\title{
Study of the Efficiency of Hybrid Subsurface Constructed Wetlands in Reducing the Organic Loading of Municipal Wastewater Treatment Plants Using Various Aquatic Plants
}

\author{
A. Haghshenas-Adarmanabadi $1^{*}$, M. Heidarpour ${ }^{1}$ and S. Tarkesh-Esfahani ${ }^{2}$
}

(Received: July 11-2015; Accepted :. April 25-2016)

\begin{abstract}
In this paper, the efficiency of four hybrid horizontal-vertical subsurface constructed wetlands which have been built for the tertiary treatment of Isfahan North Wastewater Treatment Facility and removal of organic matters was evaluated. In these constructed wetlands three plants including Phragmites australis, Typha latifolia and Arundo donax were planted and one unit left unplanted. The results of 12 months of sampling showed that the type of vegetation has no significant influence on the organic matter removal in the subsurface constructed wetlands, although the removal efficiencies in the planted constructed wetlands were more than unplanted control one. The COD and $\mathrm{BOD}_{5}$ removal efficiency in the constructed wetlands changes between $77 \%$ to $83 \%$ and $84 \%$ to $86 \%$, respectively, during the operation period. The results of this research also showed that the organic matter removal was dependent on the influent organics nature and biodegradability. The first order model constants were calibrated in different wetlands for designing main projects. The organic concentration in the wetland effluents met the Iranian regulation limits for different reuse applications that shows the constructed wetland is a suitable technology for wastewater treatment in Iran.
\end{abstract}

Keywords: Constructed wetland, COD, BOD, plant, wastewater recycling.

1. Dept. of Water Eng., College of Agr., Isfahan Univ. of Technol., Isfahan, Iran.

2. Dept. of Civil Eng., Science and Research Branch, Islamic Azad Univ., Tehran, Iran.

*: Corresponding Author, Email: haghshenasamir@yahoo.com 